Prepared in cooperation with the city of West Branch and the National Park Service

\title{
Flood-Inundation and Flood-Mitigation Modeling of the West Branch Wapsinonoc Creek Watershed in West Branch, lowa
}
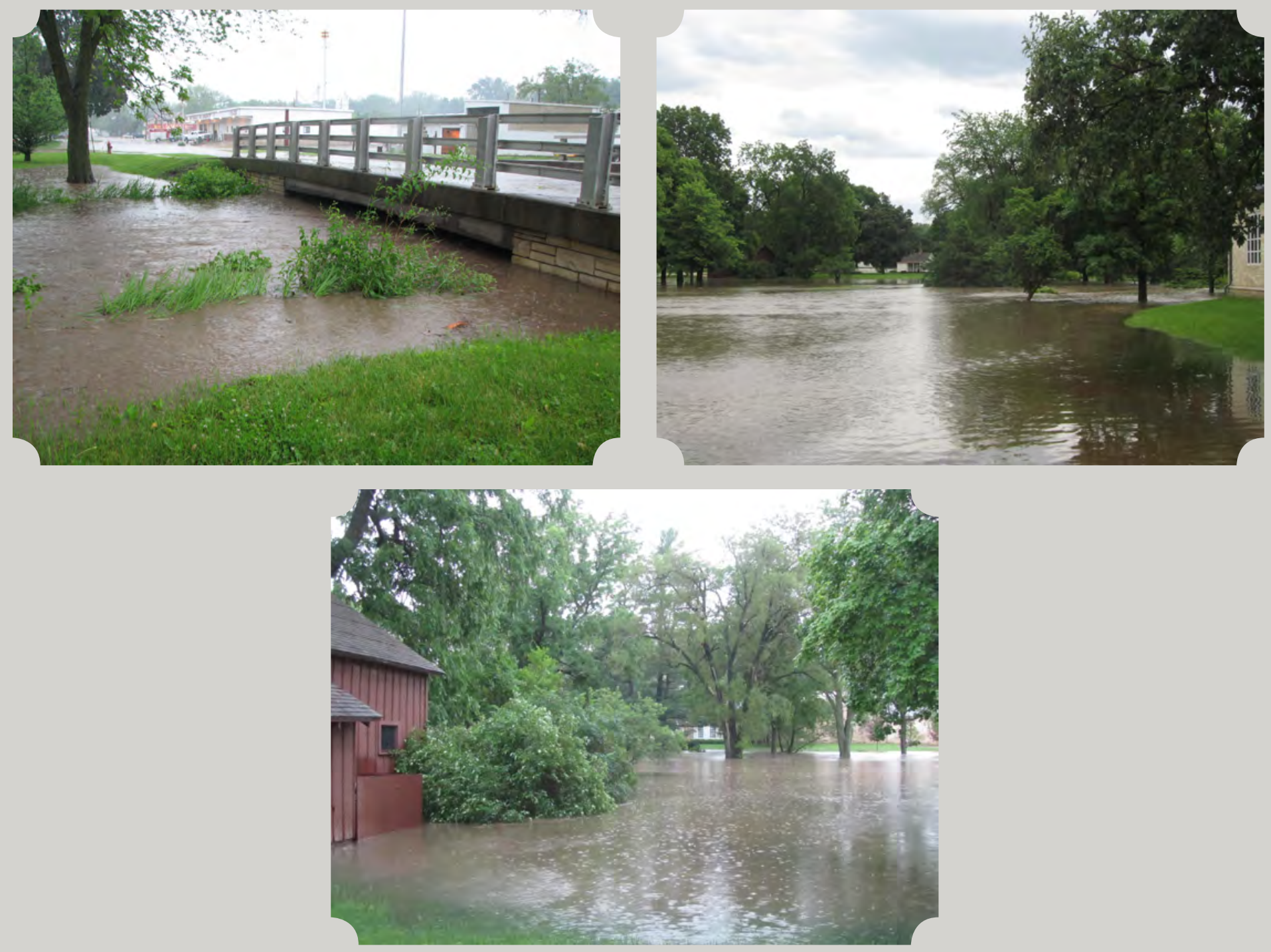

Scientific Investigations Report 2018-5002 


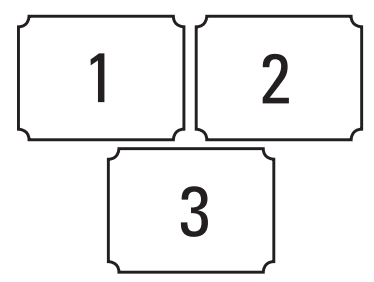

Cover. 1. Hoover Creek as it approaches the Parkside Drive bridge in West Branch, lowa, during the June 3, 2008, flood event. 2. Looking downstream (east) at Hoover Creek out of its banks inside the Herbert Hoover National Historic Site during the June 30, 2014, flood event.

3. Looking across (southwest) Hoover Creek as it flows out of its banks inside the Herbert Hoover National Historic Site during the June 30, 2014, flood event.

Photographs courtesy of the National Park Service at the Herbert Hoover National Historic Site 


\section{Flood-Inundation and Flood-Mitigation Modeling of the West Branch Wapsinonoc Creek Watershed in West Branch, lowa}

By Charles V. Cigrand

Prepared in cooperation with the

city of West Branch and the National Park Service

Scientific Investigations Report 2018-5002 


\title{
U.S. Department of the Interior \\ RYAN K. ZINKE, Secretary
}

\section{U.S. Geological Survey William H. Werkheiser, Deputy Director exercising the authority of the Director}

\author{
U.S. Geological Survey, Reston, Virginia: 2018
}

For more information on the USGS - the Federal source for science about the Earth, its natural and living resources, natural hazards, and the environment-visit https://www.usgs.gov or call 1-888-ASK-USGS.

For an overview of USGS information products, including maps, imagery, and publications, visit https://store.usgs.gov.

Any use of trade, firm, or product names is for descriptive purposes only and does not imply endorsement by the U.S. Government.

Although this information product, for the most part, is in the public domain, it also may contain copyrighted materials as noted in the text. Permission to reproduce copyrighted items must be secured from the copyright owner.

Suggested citation:

Cigrand, C.V., 2018, Flood-inundation and flood-mitigation modeling of the West Branch Wapsinonoc Creek Watershed in West Branch, lowa: U.S. Geological Survey Scientific Investigations Report 2018-5002, 36 p., https://doi.org/10.3133/sir20185002.

ISSN 2328-0328 (online) 


\section{Acknowledgments}

The author wishes to thank the many local, State, and Federal agencies that have cooperated in the funding for the operation and maintenance of the streamgages and precipitation gages used for this study. Special thanks are given to the city of West Branch and the National Park Service for the funding and cooperation of this study. 



\section{Contents}

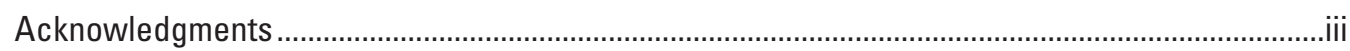

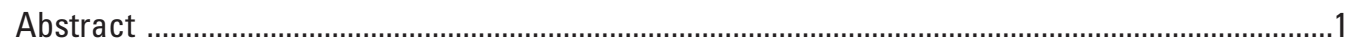

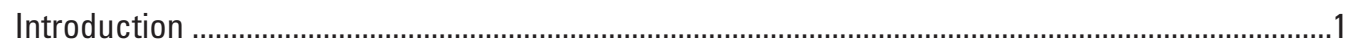

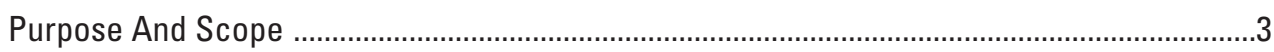

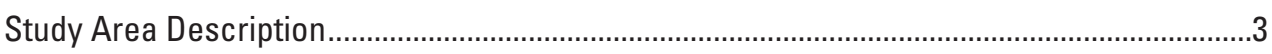

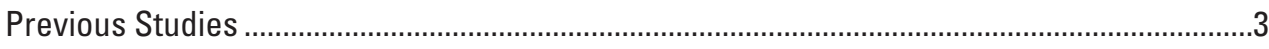

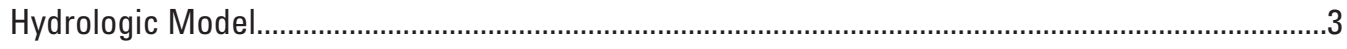

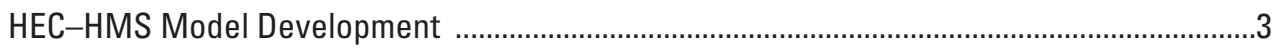

Precipitation Data And Distribution ................................................................................

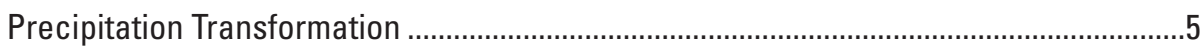

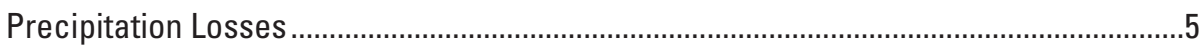

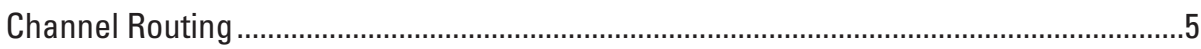

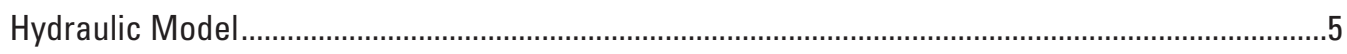

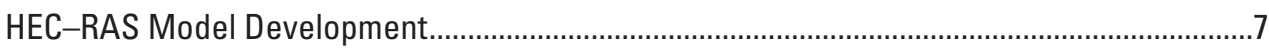

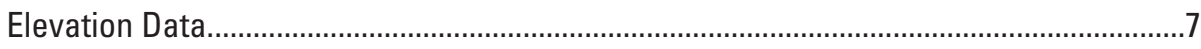

Model Geometry........................................................................................................

Hydraulic Structures .....................................................................................................

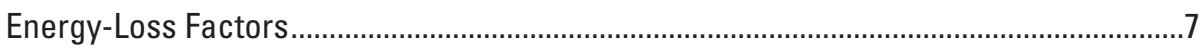

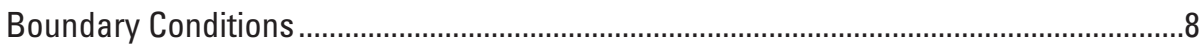

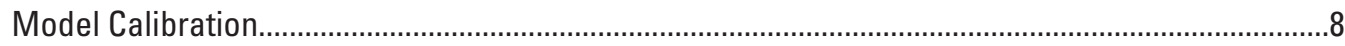

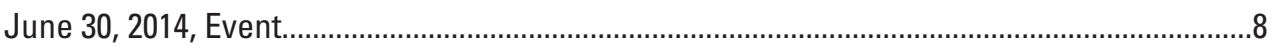

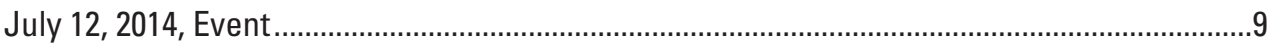

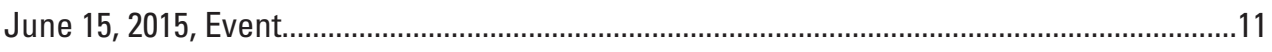

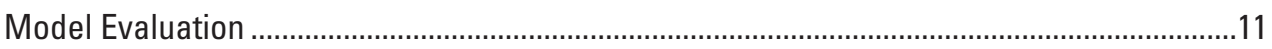

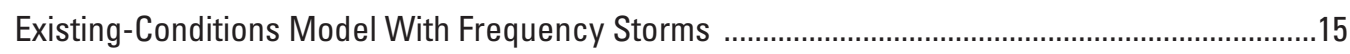

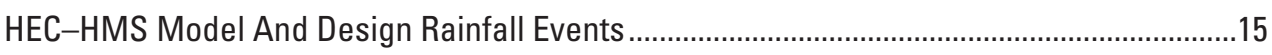

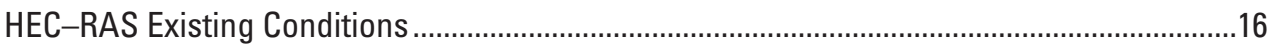

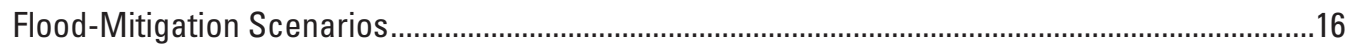

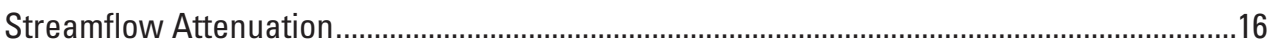

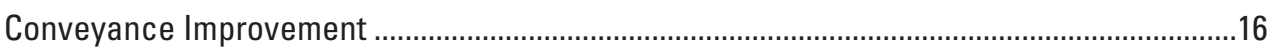

Flood-Mitigation Modeling Results..................................................................................

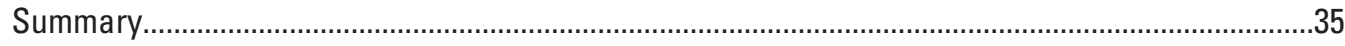

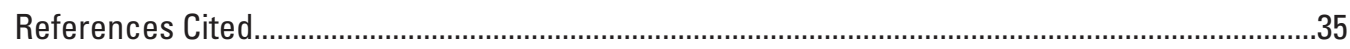

\section{Figures}

1. Map showing the location of the city of West Branch, Herbert Hoover National Historic Site, and Wapsinonoc Creek watershed ..........................................................

2. Map showing the delineation of the study area into 43 subwatersheds for the

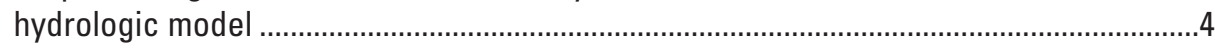

3. Map showing the location of U.S. Geological Survey precipitation gages and streamgages in the Wapsinonoc Creek watershed 
4. Graph showing $A$, the relation between the hydraulic model outputs and observed streamflow and $B$, stage at the U.S. Geological Survey streamgage on Hoover Creek (05464942) during the June 30, 2014, flood event

5. Graphs showing $A$, the relation between the hydraulic model outputs and observed streamflow and $B$, stage at the U.S. Geological Survey streamgage on Hoover Creek (05464942) during the July 12, 2014, flood event

6. Graph showing $A$, the relation between the hydraulic model outputs and observed streamflow and $B$, stage at the U.S. Geological Survey streamgage on Hoover Creek (05464942) during the June 15, 2015, high-water event

7. Graph showing $A$, the relation between the hydraulic model outputs and observed streamflow and $B$, stage at the U.S. Geological Survey streamgage on Wapsinonoc Creek (0546494170) during the June 15, 2015, high-water event

8. Map showing locations of the existing and proposed in-channel detention structures in the Wapsinonoc watershed

9. Map showing the three stream reaches and the locations of bridges, the railroad embankment, and the fire station for modeling the flood-mitigation scenarios.

10. Graph showing $A$, a cross section of the existing railroad embankment and $B$, the modifications made to improve conveyance through this structure

11. Graph showing results from simulation of a design rainfall event with 20-percent annual exceedance probability with the water-surface profiles of the Wapsinonoc Creek stream reaches

12. Graph showing results from simulation of a design rainfall event with 10-percent annual exceedance probability with the water-surface profiles of the Wapsinonoc Creek stream reaches

13. Graph showing results from simulation of a design rainfall event with 4-percent annual exceedance probability with the water-surface profiles of the Wapsinonoc Creek stream reaches

14. Graph showing results from simulation of a design rainfall event with 2-percent annual exceedance probability with the water-surface profiles of the Wapsinonoc Creek stream reaches

15. Graph showing results from simulation of a design rainfall event with 1-percent annual exceedance probability with the water-surface profiles of the Wapsinonoc Creek stream reaches

16. Graph showing results from simulation of a design rainfall event with 20-percent annual exceedance probability with water-surface profiles of Hoover Creek and Wapsinonoc Creek downstream from Hoover Creek.

17. Graph showing results from simulation of a design rainfall event with 10-percent annual exceedance probability with water-surface profiles of Hoover Creek and Wapsinonoc Creek downstream from Hoover Creek.

18. Graph showing results from simulation of a design rainfall event with 4-percent annual exceedance probability with water-surface profiles of Hoover Creek and Wapsinonoc Creek downstream from Hoover Creek.

19. Graph showing results from simulation of a design rainfall event with 2-percent annual exceedance probability with water-surface profiles of Hoover Creek and Wapsinonoc Creek downstream from Hoover Creek.

20. Graph showing results from simulation of a design rainfall event with 1-percent annual exceedance probability with water-surface profiles of Hoover Creek and Wapsinonoc Creek downstream from Hoover Creek. 


\section{Tables}

1. U.S. Geological Survey precipitation gages used in calibrating the hydrologic model of the Wapsinonoc Creek watershed.

2. U.S. Geological Survey streamgages used in calibrating both the hydrologic and hydraulic models of the Wapsinonoc Creek watershed.

3. Peak streamflows at the Hoover Creek U.S. Geological Survey streamgage (05464942) located at the Herbert Hoover National Historic Site

4. Comparison of surveyed high-water marks and modeled water-surface elevations for the June 30, 2014, flood event in the Wapsinonoc Creek watershed....

5. Observed and simulated peak streamflow, peak stage, and runoff volume from the U.S. Geological Survey streamgages $(05464942,0546494170)$ and the hydraulic model for the three historic rainfall events used to calibrate the hydrologic and hydraulic models of the Wapsinonoc Creek watershed.

6. Nash-Sutcliffe efficiency and percent bias statistic values at U.S. Geological Survey streamgages $(05464942,0546494170)$ used to calibrate the hydrologic and hydraulic models of the Wapsinonoc Creek watershed.

7. National Oceanic and Atmospheric Administration (NOAA) Atlas 14 precipitation-frequency estimates of 24-hour rainfall duration from the partial duration series for the Wapsinonoc Creek watershed (Perica and others, 2013)

8. Peak streamflows from the design rainfall events with the existing conditions hydraulic model at the Hoover Creek U.S. Geological Survey streamgage (05464942) located at the Herbert Hoover National Historic Site

9. Proposed and existing in-channel detention structures with their associated drainage area, storage capacity, dam height, and outlet culvert size

10. Water-surface elevations from design rainfall events for the different flood mitigation scenarios compared to the existing conditions within the Wapsinonoc Creek watershed. 


\section{Conversion Factors}

U.S. customary units to International System of Units

\begin{tabular}{lcl}
\hline \multicolumn{1}{c}{ Multiply } & By & \multicolumn{1}{c}{ To obtain } \\
\hline foot $(\mathrm{ft})$ & Length & \\
mile (mi) & 0.3048 & meter $(\mathrm{m})$ \\
\hline & 1.609 & kilometer $(\mathrm{km})$ \\
\hline square mile $\left(\mathrm{mi}^{2}\right)$ & Area & \\
\hline & 2.590 & square kilometer $\left(\mathrm{km}^{2}\right)$ \\
\hline acre-foot $($ acre-ft) & Volume & \\
\hline & 1,233 & cubic meter $\left(\mathrm{m}^{3}\right)$ \\
\hline cubic foot per second $\left(\mathrm{ft}^{3} / \mathrm{s}\right)$ & Flow rate & \\
\hline
\end{tabular}

\section{Datum}

Vertical coordinate information is referenced to the North American Vertical Datum of 1988 (NAVD 88).

Horizontal coordinate information is referenced to the North American Datum of 1983 (NAD 83).

Elevation, as used in this report, refers to distance above the vertical datum. 


\title{
Flood-Inundation and Flood-Mitigation Modeling of the West Branch Wapsinonoc Creek Watershed in West Branch, lowa
}

\author{
By Charles V. Cigrand
}

\section{Abstract}

The U.S. Geological Survey (USGS) in cooperation with the city of West Branch and the Herbert Hoover National Historic Site of the National Park Service assessed flood-mitigation scenarios within the West Branch Wapsinonoc Creek watershed. The scenarios are intended to demonstrate several means of decreasing peak streamflows and improving the conveyance of overbank flows from the West Branch Wapsinonoc Creek and its tributary Hoover Creek where they flow through the city and the Herbert Hoover National Historic Site located within the city.

Hydrologic and hydraulic models of the watershed were constructed to assess the flood-mitigation scenarios. To accomplish this, the models used the U.S. Army Corps of Engineers Hydrologic Engineering Center-Hydrologic Modeling System (HEC-HMS) version 4.2 to simulate the amount of runoff and streamflow produced from single rain events. The Hydrologic Engineering Center-River Analysis System (HEC-RAS) version 5.0 was then used to construct an unsteady-state model that may be used for routing streamflows, mapping areas that may be inundated during floods, and simulating the effects of different measures taken to decrease the effects of floods on people and infrastructure.

Both models were calibrated to three historic rainfall events that produced peak streamflows ranging between the 2-year and 10-year flood-frequency recurrence intervals at the USGS streamgage (05464942) on Hoover Creek. The historic rainfall events were calibrated by using data from two USGS streamgages along with surveyed high-water marks from one of the events. The calibrated HEC-HMS model was then used to simulate streamflows from design rainfall events of 24-hour duration ranging from a 20-percent to a 1-percent annual exceedance probability. These simulated streamflows were incorporated into the HEC-RAS model.

The unsteady-state HEC-RAS model was calibrated to represent existing conditions within the watershed. HECRAS model simulations with the existing conditions and streamflows from the design rainfall events were then done to serve as a baseline for evaluating flood-mitigation scenarios. After these simulations were completed, three different flood-mitigation scenarios were developed with HEC-RAS: a detention-storage scenario, a conveyance improvement scenario, and a combination of both. In the detention-storage scenario, four in-channel detention structures were placed upstream from the city of West Branch to attenuate peak streamflows. To investigate possible improvements to conveying floodwaters through the city of West Branch, a section of abandoned railroad embankment and an old truss bridge were removed in the model, because these structures were producing backwater areas during flooding events. The third scenario combines the detention and conveyance scenarios so their joint efficiency could be evaluated. The scenarios with the design rainfall events were run in the HEC-RAS model so their flood-mitigation effects could be analyzed across a wide range of flood magnitudes.

\section{Introduction}

The city of West Branch is located in east central Iowa along Interstate 80 in Cedar and Johnson counties (fig. 1). The city has a population of approximately 2,322 (U.S. Census Bureau, 2010) and is also the hometown of President Herbert Hoover, the 31st President of the United States. In 1965 the Herbert Hoover National Historic Site (HEHO) was dedicated to the former President in the city of West Branch (National Park Service, 2017). The HEHO is operated and maintained by the National Park Service (NPS) and contains historical sites such as:

- the Herbert Hoover Presidential Library and Museum;

- the gravesites of the former President and First Lady Hoover;

- President Hoover's birthplace cottage;

- President Hoover's childhood one-room schoolhouse;

- Friends Meeting House, a place of worship for the local Quakers and Hoover family; and

- other historical structures. 


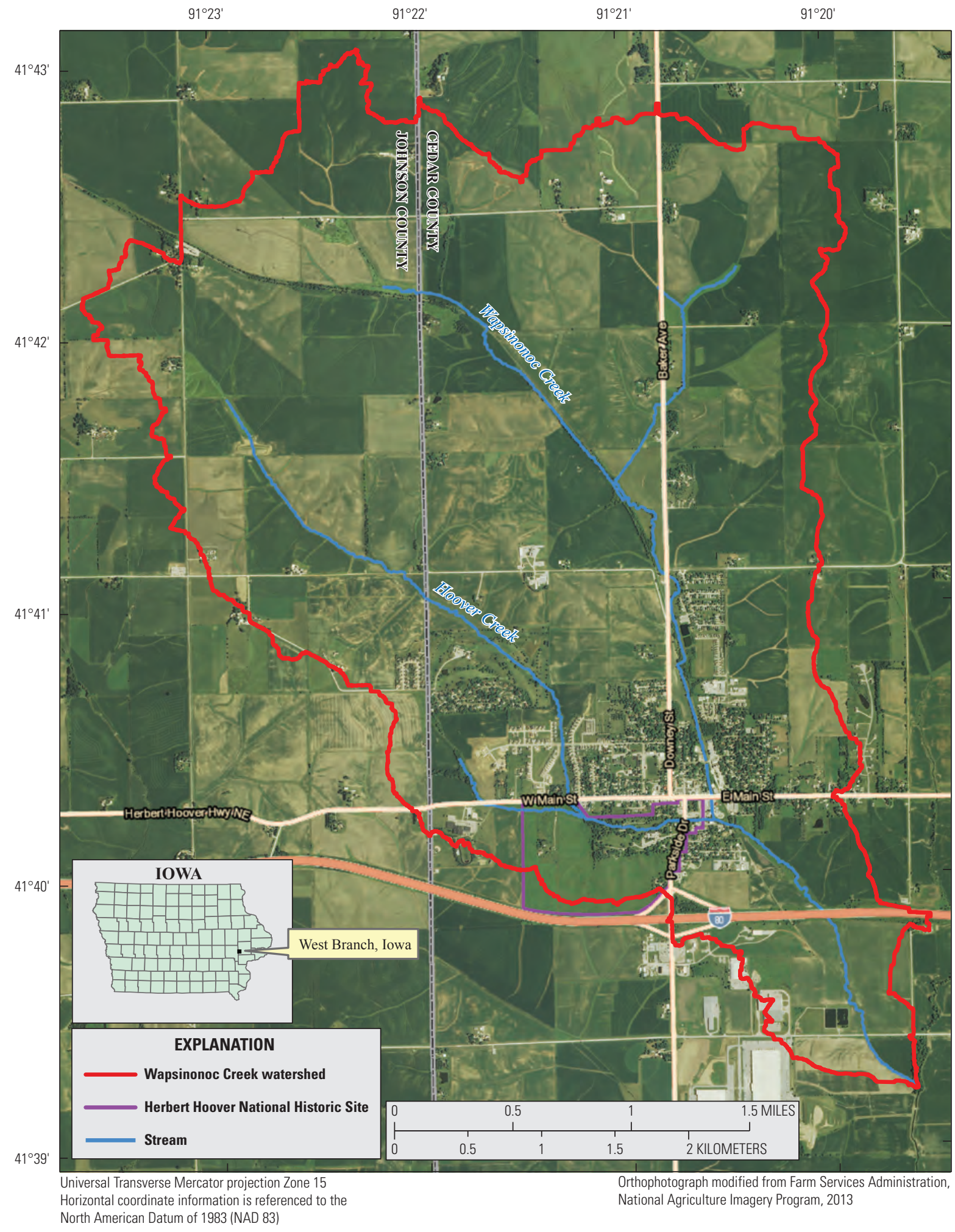

Figure 1. The location of the city of West Branch, Herbert Hoover National Historic Site, and Wapsinonoc Creek watershed. 
These historical sites along with the city of West Branch are prone to flash-flooding events after intense rainfall. The presence of railroad and interstate highway embankments, bridges, and buildings in the flood plain have added further complications to the flooding (Federal Emergency Management Agency, 2013). Some of these structures are known to create backwater areas which affect the city and HEHO according to the city engineer of West Branch, David Schechinger (oral commun., 2016). From 1991 to 2003, 18 flood events inundated park buildings and infrastructure at HEHO (NPS, 2006). From 2003 to 2016, Hoover Creek reached or exceeded the 2-year flood-frequency recurrence interval 11 times according to the USGS streamgage (05464942) located on Hoover Creek within HEHO (Eash, 2015).

\section{Purpose and Scope}

The purpose of this report is to evaluate selected floodmitigation scenarios for their effectiveness of reducing peak streamflows and improving streamflow conveyance through known backwater areas in the Wapsinonoc Creek watershed. The procedures applied in constructing the hydrologic and hydraulic models used to simulate flood-mitigation scenarios with design rainfall events of 24-hour duration ranging from a 20 -percent to a 1-percent annual exceedance probability will be described in this report.

\section{Study Area Description}

The city of West Branch and HEHO are located within an 8.42-square mile $\left(\mathrm{mi}^{2}\right)$ watershed of the West Branch Wapsinonoc Creek, a tributary to the Cedar River, hereinafter referred to as "Wapsinonoc Creek." This area lies within the Southern Iowa Drift Plain landform region, which consists of loess mantled Pre-Illinoian glacial till with a well-integrated drainage network of rills and streams (Prior, 1991). The major streams flow through broad flood plains flanked by steep-sided hills and ridges with a high rate of runoff (Iowa Highway Research Board, 1957). Wapsinonoc Creek enters the city of West Branch from the north and flows through the middle of town before exiting the town's southeast corner. Hoover Creek enters the city of West Branch from the northwest flowing in a south-southeast direction. It then flows easterly through HEHO before its confluence with the Wapsinonoc Creek within the southern portion of town.

\section{Previous Studies}

A flood-reduction study of this watershed was conducted by the Iowa Institute of Hydraulic Research (Iowa Institute of Hydraulic Research, 2010). The hydrologic study investigated reducing peak flows with water detention structures by means of also using land-use management practices to reduce storm runoff. To construct a hydrologic model, The Iowa Institute of Hydraulic Research used the Natural Resource Conservation Service, previously known as the Soil Conservation Service (SCS), methodologies from the Technical Release 55 (TR-55) (SCS, 1986) to construct a hydrologic model.

An engineering report for the Hoover Creek portion of the watershed presents an analysis of the instabilities of Hoover Creek and flood-mitigation alternatives for up to a 50-year flood-recurrence interval (Parsons Engineering Corporation, 2006). The flood-mitigation alternatives include various channel modifications and water detention structures. The analysis used a Hydrologic Engineering Center-1 hydrologic model and Hydrologic Engineering Center-River Analysis System (HEC-RAS) hydraulic model. The report also describes the estimated costs for proposed modifications and structures.

A comprehensive report of previous studies from the Hoover Creek Watershed was prepared by the NPS (2006). This report goes over the pros and cons of flood-mitigation alternatives proposed by the Parsons Engineering Corporation (2006) report. The report also presents an analysis of an environmental impact statement for these alternatives, and the NPS found no major environmental impacts or impairments to park resources or values.

\section{Hydrologic Model}

A hydrologic model was used to simulate the timing and amount of streamflow for the Wapsinonoc Creek watershed. The hydrologic model was constructed using the U.S. Army Corps of Engineers (USACE) modeling system Hydrologic Engineering Center-Hydrologic Modeling System (HEC-HMS) version 4.2, which was designed to simulate the precipitation-runoff processes of dendritic watershed systems (USACE, 2016a). The HEC-HMS model was calibrated to three historic rainfall events that produced flash flooding within the watershed. The calibrated HEC-HMS model was then used to simulate precipitation-runoff from design rainfall events covering a range of magnitudes. Output hydrographs from the HEC-HMS model were then used as inputs for the hydraulic model (see "Hydraulic Model" section).

\section{HEC-HMS Model Development}

The HEC-HMS model was constructed with the HECGeospatial Hydrologic Modeling Extension (HEC-GeoHMS) (USACE, 2013) version 10.2, which is used through a geographic information system (GIS) to build the model framework and to estimate initial model parameters. Through HEC-GeoHMS, a 3-meter digital elevation model (DEM) and a stream centerline dataset were used to delineate the $8.42-\mathrm{mi}^{2}$ watershed and to define the stream network (State of Iowa, 2017). This watershed was further delineated into 


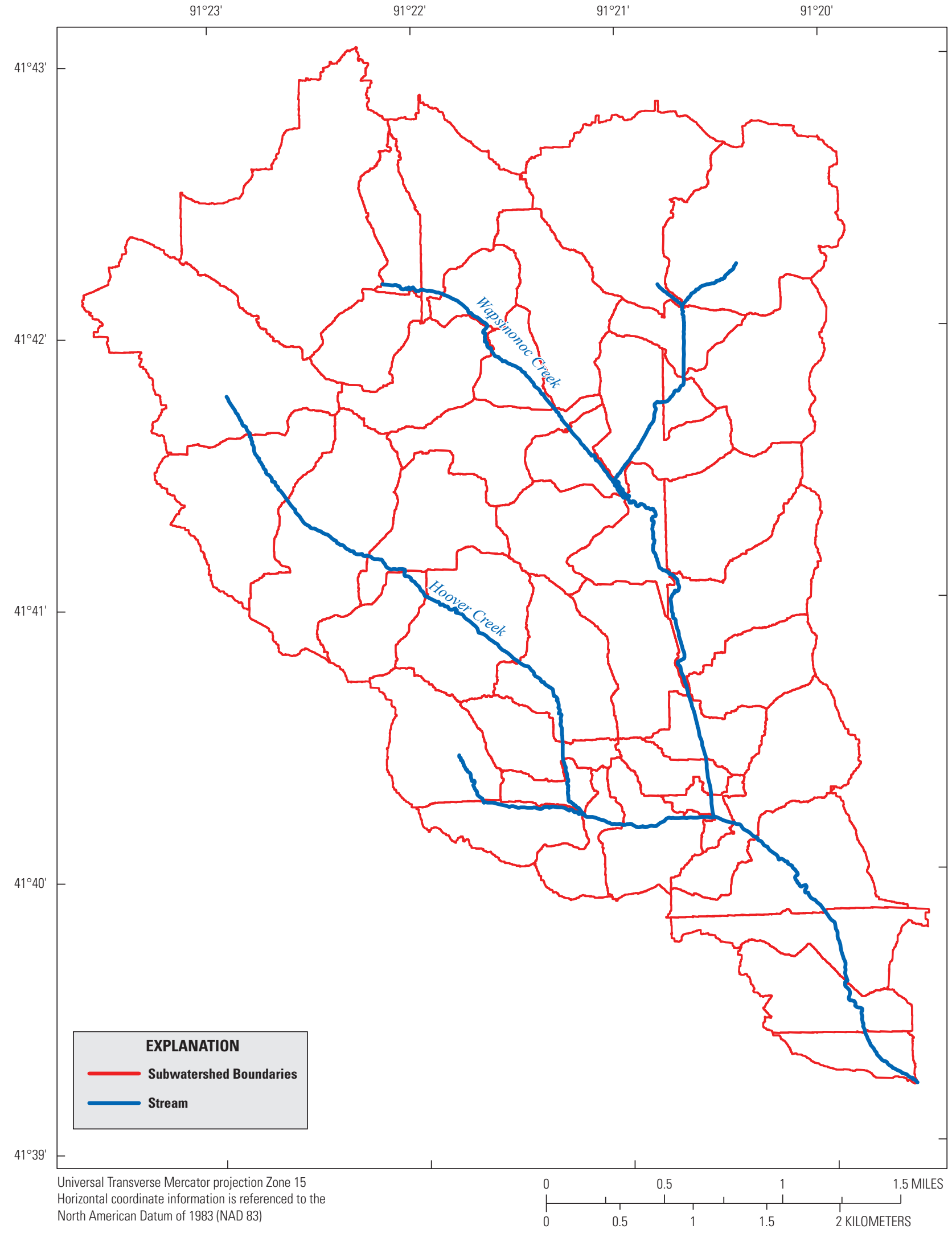

Figure 2. The delineation of the study area into 43 subwatersheds for the hydrologic model. 
43 subwatersheds (fig. 2) in order to serve as a basic unit for parameter assignment and to segment the stream network for the hydraulic model boundary conditions.

\section{Precipitation Data and Distribution}

In order to simulate a precipitation runoff event, hydrologic models need accurate temporal and spatial precipitation data for the watershed. The USGS precipitation gages used in this study record fallen precipitation in 15-minute time steps. Two USGS precipitation gages (414209091215801, 414208091204701) are located within the watershed and have been operational since April of 2015 (fig. 3 and table 1). A third USGS precipitation gage (414345091253801) is located within the adjoining watershed of Rapid Creek and is approximately 3 miles northwest from the Wapsinonoc Creek watershed (fig. 3 and table 1). This gage dates back to 1994 and was used for a historic rainfall event predating the precipitation gages located within the study area. Next Generation Radar (NEXRAD) Multi-sensor Precipitation Estimator (MPE) hourly precipitation data were also used in the HEC-HMS model for a historic rainfall event (National Oceanic and Atmospheric Administration, 2016).

\section{Precipitation Transformation}

During a rainfall event, excess precipitation can outpace soil infiltration rates, surface storage availability, and tree canopy interception. This excess precipitation is transformed into a hydrograph representing the direct runoff from a rainfall event by using the Clark (1945) unit-hydrograph method. The HEC-HMS model needed two parameters for this unit-hydrograph method, time of concentration $\left(T_{\mathrm{c}}\right)$ and a storage coefficient $(R)$. The $T_{\mathrm{c}}$ is the time of travel it takes for precipitation runoff to propagate from the most distant point in a watershed to the watershed outlet. $R$ is a storage coefficient used to account for storage within the flood plain such as wetlands, reservoirs, and bridges that can produce flood-wave attenuation. Initial $T_{\mathrm{c}}$ estimates were calculated using the TR-55 methodology (SCS, 1986). A dimensionless ratio $R /\left(T_{\mathrm{c}}+R\right)$ has been found to be fairly consistent for watersheds on a regional basis (USACE, 1994). $R$ storage coefficient values were set to the initial $T_{\mathrm{c}}$ values for the subwatersheds and further adjusted during calibration.

\section{Precipitation Losses}

Precipitation losses account for hydrologic processes such as tree canopy interception, storage losses, and subsurface infiltration. The SCS Curve Number (CN) method was used to simulate precipitation losses; CNs were applied to each subwatershed according to the TR-55 methodology (SCS, 1986), which uses hydrologic soil type, land use, land treatment, and antecedent runoff conditions. Composite $\mathrm{CNs}$ for each subwatershed were determined through
HEC-GeoHMS by using spatial data from the Soil Survey Geographic database (U.S. Department of Agriculture, 2016) and the National Land Cover Database 2011 edition (Homer and others, 2015).

The antecedent runoff conditions are divided into three classes: $C N(I)$ for dry soil conditions, $C N(I I)$ for average soil moisture conditions, and $C N(I I I)$ for saturated soil conditions (Natural Resource Conservation Service, 2004). The GeoHMS-derived CNs were for $C N(I I)$. The $C N(I I)$ and $C N(I I I)$ were used as the lower and upper $\mathrm{CN}$ ranges in the HEC-HMS model calibration. CN(III) can be computed from $C N(I I)$ with the following equation (Chow and others, 1988):

$$
C N(I I I)=\frac{23 C N(I I)}{10+0.13 C N(I I)},
$$

The recession base-flow method (Chow and others, 1988) was used to simulate base flow within the watershed. For this method the HEC-HMS model needed three parameters: initial discharge, recession constant, and the base-flow-threshold ratio to peak constant. The initial discharge was applied to the subwatersheds as a ratio of cubic feet per second per square mile $\left[\left(\mathrm{ft}^{3} / \mathrm{s}\right) / \mathrm{mi}^{2}\right]$. The recession constant represents the rate at which base flow recedes following a rainfall event. The baseflow-threshold ratio to peak constant distinguishes when to begin base flow on the receding limb of a hydrograph. These parameters were estimated and applied during the HEC-HMS model calibration.

\section{Channel Routing}

Channel routing was conducted through the unsteadystate HEC-RAS model, which solves the full, unsteady flow equations described in the "Hydraulic Model" section. This modeling approach was chosen over hydrologic routing methods available in HEC-HMS to better represent flood plain storage and backwater effects within the watershed. Thus, model calibration for both the HEC-HMS and HEC-RAS models were done simultaneously as an interactive process.

\section{Hydraulic Model}

A combined one-dimensional (1D) and two-dimensional (2D) unsteady-state hydraulic model was used to simulate streamflows and their associated water-surface elevations (WSEs) in order to delineate areas of flood inundation. The hydraulic model was constructed using the USACE modeling program HEC-RAS version 5.0.3 (USACE, 2016b). An unsteady-state hydraulic model routes streamflow hydrographs to account for flood-wave attenuation and storage within the flood plain. A combined 1D/2D HEC-RAS model uses 1D capabilities in part of the model and 2D capabilities in other parts of the model. This method was used so hydraulically complex areas such as stream junctions and skewed embankments to the flood plain could be modeled in 2D. The 


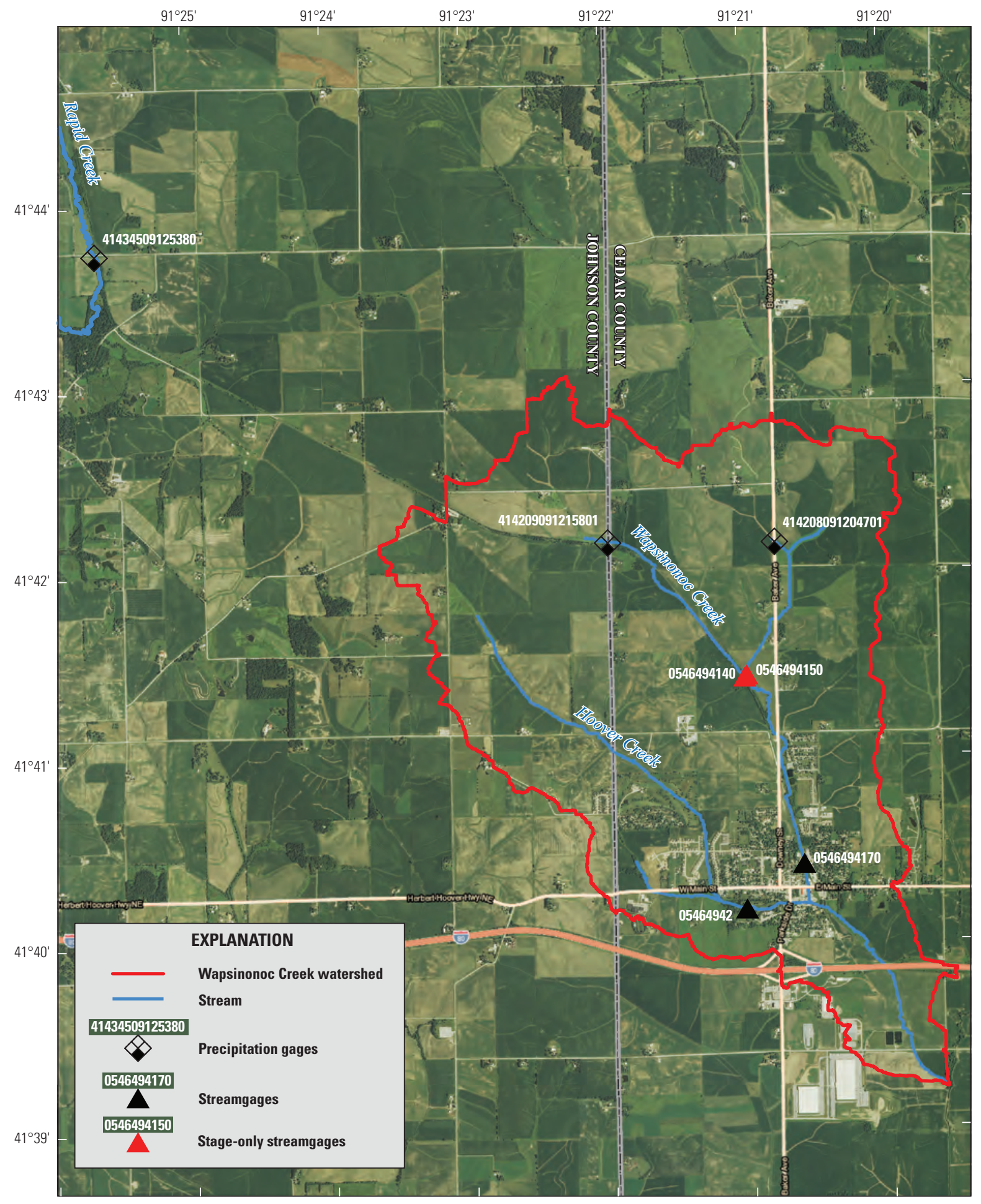

Universal Transverse Mercator projection Zone 15

Orthophotograph modified from Farm Services Administration, Horizontal coordinate information is referenced to the National Agriculture Imagery Program, 2013 North American Datum of 1983 (NAD 83)

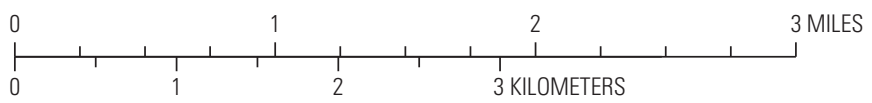

Figure 3. The location of U.S. Geological Survey precipitation gages and streamgages in the Wapsinonoc Creek watershed. 
Table 1. U.S. Geological Survey precipitation gages used in calibrating the hydrologic model of the Wapsinonoc Creek watershed.

[USGS, U.S. Geological Survey; latitude and longitude in decimal degrees; IA, Iowa]

\begin{tabular}{clccc}
\hline $\begin{array}{c}\text { USGS station } \\
\text { number }\end{array}$ & \multicolumn{1}{c}{ USGS gage name } & $\begin{array}{c}\text { Latitude } \\
\text { (north) }\end{array}$ & $\begin{array}{c}\text { Longitude } \\
\text { (west) }\end{array}$ & Period of record \\
\hline 414345091253801 & Precipitation gage at Rapid Creek below Morse, IA & 41.729 & -91.427 & March 1, 1994-present \\
414209091215801 & Precipitation gage at County Line Road at West Branch, IA & 41.703 & -91.366 & April 21, 2015-January 24, 2017 \\
414208091204701 & Precipitation gage at Baker Avenue at West Branch, IA & 41.702 & -91.347 & April 21, 2015-January 24, 2017 \\
\hline
\end{tabular}

HEC-RAS model was calibrated to the same historic rainfall events as the HEC-HMS model. The calibrated HEC-RAS model was then used to analyze the effects of proposed floodmitigation scenarios.

\section{HEC-RAS Model Development}

The HEC-RAS model was constructed using the GIS extension HEC-GeoRAS (USACE, 2012) version 10.2 to build the model framework.

\section{Elevation Data}

All elevation data used in this study are referenced vertically to the North American Vertical Datum of 1988 and horizontally to the North American Datum of 1983. The bare-earth DEM used for this study was derived from light detection and ranging data that were collected as part of a statewide project during 2007-10 (State of Iowa, 2017). The DEM has 1-meter resolution and represents the elevation of the Earth with all man-made structures and vegetation removed.

Because light detection and ranging data cannot penetrate water, channel survey data below the water-surface were collected by USGS field personnel during the spring of 2016. The data were collected using an Ashtek ProMark 800 Global Navigation Satellite System with Real-Time Network surveying techniques.

\section{Model Geometry}

The HEC-RAS model consisted of 4 reaches of the Wapsinonoc Creek, 2 reaches of Hoover Creek, and 2 tributaries totaling 257 cross sections and 9.7 miles. Six 2D areas were also incorporated into the model. These areas include stream junctions and highly skewed embankments that were found to be hydraulically complex and more accurately modeled in $2 \mathrm{D}$.

\section{Hydraulic Structures}

Twenty-four bridges and culverts were incorporated into the model because they have the potential to affect watersurface elevations during flooding events. Bridge and culvert geometry data were obtained from field surveys led by personnel from the USGS during the spring of 2016 and from bridge plans obtained from the Johnson and Cedar County Secondary Road Departments and the city of West Branch Public Works Department. Additionally, the abandoned railroad embankment along with the existing and proposed in-channel detention structures were incorporated into the model as inline structures.

\section{Energy-Loss Factors}

Hydraulic analyses require the estimation of energy losses that result from frictional flow resistance. These energy losses are quantified by the Manning's roughness coefficient ( $n$-value; Chow, 1959). Initial (precalibration) $n$-values were selected on the basis of field observations (Barnes, 1967) and high-resolution aerial photographs from the U.S. Department of Agriculture's National Agriculture Imagery Program. These initial $n$-values were adjusted as part of the calibration process, which involved minimizing the differences between simulated and observed water-surface elevations at the streamgages and where surveyed high-water marks (HWMs) were collected.

Calibrated main channel $n$-values ranged from 0.033 to 0.060 except for two locations, the Downey Street Bridge and the truss bridge, which needed elevated $n$-values to replicate observed water-surface profiles. The Downey Street Bridge was assigned a $0.100 n$-value, which was justified by two large pipes and fence posts that were exposed across the main channel with the fence posts holding them in place. A 0.080 $n$-value was applied at the truss bridge, because a large amount of woody vegetation spanned the main channel in front of this bridge. The 0.033 to 0.04 channel $n$-values accounted for sections of stream with little to no woody vegetation, and the 0.045 to 0.060 channel $n$-values accounted for much of the woody vegetation growing along the banks and canopying the main channel.

Calibrated overbank $n$-values ranged from 0.040 to 0.150 . The 0.040 to 0.055 overbank $n$-values represented overbank areas consisting of large mowed areas with few obstructions, agricultural fields, and grasslands. The 0.060 to 0.150 overbank $n$-values represented urban areas with many obstructions and densely wooded or brushy areas. 


\section{Boundary Conditions}

Flow hydrographs from the HEC-HMS model were used as the upstream boundary condition, and normal depth was used as the downstream boundary condition. The HEC-HMS model created flow hydrographs for the 43 subwatersheds delineated within the study area. The flow hydrographs of the subwatersheds were used as upstream boundary conditions for the subwatersheds located upstream from the beginning of a stream reach in the HEC-RAS model. The remaining subwatershed flow hydrographs were added to the model as lateral inflows along a reach. The downstream boundary condition was a normal depth using a slope of 0.0015 . The slope was calculated by surveying WSEs at the downstream end of the study area, which resulted in a change of 1.64 feet (ft) in WSEs in approximately $1,080 \mathrm{ft}$ of stream.

\section{Model Calibration}

Calibration of the HEC-HMS and HEC-RAS models was difficult due to a very responsive stream network with limited availability of temporal rainfall data within the watershed. During calibration, $C N s, T_{\mathrm{c}}$, and $R$ parameters were adjusted in the HEC-HMS model. The $C N s$ governed how much precipitation was converted to direct runoff. The $T_{\mathrm{c}}$ parameter affected the timing of the hydrograph, and the $R$ parameter influenced hydrograph attenuation. Ineffective flow areas and Manning's $n$-values were adjusted to calibrate the HEC-RAS model. These HEC-RAS parameters primarily affected WSEs and hydrograph attenuation.

The models were calibrated to three historic rainfall events occurring on: June 30, 2014, July 12, 2014, and June 15,2015 . Four USGS streamgages (05464942, 0546494170 , 0546494140, 0546494150) are located within the watershed: two being stage-only streamgages $(0546494140,0546494150)$ (fig. 3; table 2). Three of the streamgages (0546494170, 0546494140,0546494150 ) could only be used to calibrate the most recent historic rainfall event because they were not in operation until April of 2015. The Hoover Creek streamgage (05464942), located within HEHO, has been operational since March 2000 and was used to calibrate all three historic rainfall events. The three historic rainfall events used for calibration are among the six highest peak streamflows (table 3 ) to occur at the Hoover Creek streamgage (05464942) since its operation. Two floods of greater magnitude, which predate the Hoover Creek streamgage (05464942), occurred during August 1993 and June 1967 (USGS, 2016). It is also important to note that the April 17, 2013, historic rainfall event was not used for model calibration. Precipitation data from the Rapid Creek precipitation gage (414345091253801) in the neighboring watershed and NEXRAD MPE hourly precipitation data both underestimate rainfall within the study area for this event (USGS, 2016; National Oceanic and Atmospheric Administration, 2016) to such a degree that modeling could not accurately replicate the April 17, 2013 event.

\section{June 30, 2014, Event}

The June 30, 2014, event produced the highest recorded stage on record and had a peak streamflow of $705 \mathrm{ft}^{3} / \mathrm{s}$ at the Hoover Creek streamgage (05464942). This runoff event was produced by two successive rounds of storms passing over the study area within hours of each other. The Rapid Creek precipitation gage (414345091253801) was the nearest precipitation gage with hourly or subhourly temporal data. According to this gage, approximately 3 in. of rainfall accumulated; the peak 15 -minute rainfall intensity was 0.77 in. during the first round of storms and 0.63 in. during the second round of storms. The precipitation fell on saturated soil conditions from

Table 2. U.S. Geological Survey streamgages used in calibrating both the hydrologic and hydraulic models of the Wapsinonoc Creek watershed.

[USGS, U.S. Geological Survey; latitude and longitude in decimal degrees; $\mathrm{mi}^{2}$, square miles; IA, Iowa]

\begin{tabular}{|c|c|c|c|c|c|}
\hline $\begin{array}{l}\text { USGS station } \\
\text { number }\end{array}$ & USGS gage name & $\begin{array}{l}\text { Latitude } \\
\text { (north) }\end{array}$ & $\begin{array}{l}\text { Longitude } \\
\text { (west) }\end{array}$ & $\begin{array}{c}\text { Drainage } \\
\text { area } \\
\left(\mathrm{mi}^{2}\right)\end{array}$ & Period of record \\
\hline 05464942 & $\begin{array}{l}\text { Hoover Creek at Hoover National Historic Site, } \\
\text { West Branch, IA }\end{array}$ & 41.670 & -91.351 & 2.58 & March 2, 2000-present \\
\hline 0546494170 & $\begin{array}{l}\text { West Branch Wapsinonoc Creek at College Street at } \\
\text { West Branch, IA }\end{array}$ & 41.674 & -91.344 & 4.60 & April 20, 2015-present \\
\hline${ }^{1} 0546494140$ & $\begin{array}{l}\text { West Branch Wapsinonoc Creek above Baker Avenue at } \\
\text { West Branch, IA }\end{array}$ & 41.690 & -91.350 & 1.95 & April 20, 2015-present \\
\hline${ }^{1} 0546494150$ & $\begin{array}{l}\text { Unnamed Tributary to West Branch Wapsinonoc Creek at } \\
\text { West Branch, IA }\end{array}$ & 41.691 & -91.350 & 1.46 & April 20, 2015-present \\
\hline
\end{tabular}

${ }^{1}$ Stage-only gage site. 
Table 3. Peak streamflows at the Hoover Creek U.S. Geological Survey streamgage (05464942) located at the Herbert Hoover National Historic Site.

$\left[\mathrm{ft}^{3} / \mathrm{s}\right.$, cubic feet per second; ft, feet]

\begin{tabular}{ccc}
\hline $\begin{array}{c}\text { Date of event } \\
\text { (month/date/year) }\end{array}$ & $\begin{array}{c}\text { Streamflow } \\
\left(\mathrm{ft}^{3} / \mathbf{s}\right)\end{array}$ & $\begin{array}{c}\text { Stage elevation } \\
\text { (ft) }\end{array}$ \\
\hline $08 / 16 / 1993^{1}$ & 1,650 & 715.05 \\
$06 / 07 / 1967^{1}$ & 1,500 & 715.25 \\
$04 / 17 / 2013^{2}$ & 747 & 713.40 \\
$06 / 30 / 2014^{3}$ & 705 & 714.97 \\
$07 / 12 / 2014^{3}$ & 546 & 714.05 \\
$06 / 03 / 2008$ & 404 & 714.04 \\
$06 / 18 / 2010$ & 354 & 713.52 \\
$06 / 15 / 2015^{3}$ & 329 & 712.49 \\
\hline
\end{tabular}

${ }^{1}$ Events predate gage site thus streamflow and stage are estimates.

${ }^{2}$ Insufficient rainfall data for modeling purposes.

${ }^{3}$ Events used in model calibration.

approximately 2 in. of rainfall that had already accumulated during the previous 48 hours.

The June 30, 2014, event flooded many city streets, buildings, and parts of HEHO, causing damages and leaving behind flood debris. After the flood, the city surveyed 13 HWMs along the Wapsinonoc and Hoover Creeks around the downtown area and downstream towards Interstate 80 . This survey proved valuable in model calibration because the Hoover Creek streamgage (05464942) was the only streamgage in operation within the watershed at the time. Simulated WSEs from the HEC-RAS model were within 0.7 $\mathrm{ft}$ of the 13 surveyed HWMs from the event (table 4), and all the simulated WSEs fall below the surveyed HWMs. The timing and intensity of the rainfall within the study area, particularly for the second round of storms, seemed to be slightly misrepresented by the precipitation data from the Rapid Creek precipitation gage (414345091253801) (USGS, 2016). This made it difficult to replicate the second peak in the hydrograph (fig. 4) from this rainfall event. The simulated streamflow hydrograph had a crest within $6 \mathrm{ft}^{3} / \mathrm{s}$ of the observed hydrograph, and the simulated stage hydrograph had a crest within $0.34 \mathrm{ft}$ of the observed hydrograph (table 5).

\section{July 12, 2014, Event}

The Wapsinonoc and Hoover creeks flooded out of their banks again on July 12, 2014, within 2 weeks of the flooding on June 30, 2014. This event reached a peak streamflow of $546 \mathrm{ft}^{3} / \mathrm{s}$ at the Hoover Creek streamgage (05464942). According to NEXRAD MPE hourly precipitation data, the watershed received approximately 1 to $1.5 \mathrm{in}$. of rainfall that morning, creating saturated soil conditions (National Oceanic and Atmospheric Administration, 2016). An additional 1.5 to 2 in. of intense rainfall occurred within the watershed later

Table 4. Comparison of surveyed high-water marks and modeled water-surface elevations for the June 30, 2014, flood event in the Wapsinonoc Creek watershed.

[HEC-RAS, Hydrologic Engineering Center-River Analysis System; HWMs, high-water marks; ft, feet; diff, difference equals simulated water-surface elevation minus surveyed high-water marks]

\begin{tabular}{lcccc}
\hline \multicolumn{1}{c}{ Stream } & River station in HEC-RAS & Surveyed HWMs (ft) & $\begin{array}{c}\text { Simulated water-surface } \\
\text { elevation (ft) }\end{array}$ & diff (ft) \\
\hline Hoover Creek & 1,297 & 713.55 & 713.32 & -0.23 \\
Hoover Creek & 353 & 710.89 & 710.49 & -0.40 \\
Hoover Creek & 286 & 710.85 & 710.17 & -0.68 \\
Hoover Creek & 60 & 710.08 & 709.79 & -0.29 \\
Wapsinonoc Creek & 9,040 & 711.35 & 710.85 & -0.50 \\
\hline Wapsinonoc Creek & 8,471 & 710.10 & 709.79 & -0.31 \\
Wapsinonoc Creek & 8,216 & 709.67 & 709.30 & -0.37 \\
Wapsinonoc Creek & 8,073 & 709.51 & 708.91 & -0.60 \\
\hline Wapsinonoc Creek & 8,008 & 708.71 & 708.25 & -0.46 \\
\hline Wapsinonoc Creek & 7,639 & 707.87 & 707.57 & -0.30 \\
\hline Wapsinonoc Creek & 6,910 & 706.30 & 706.12 & -0.18 \\
\hline Wapsinonoc Creek & 6,514 & 705.53 & 705.19 & -0.34 \\
Wapsinonoc Creek & 5,434 & 704.32 & 703.85 & -0.47 \\
\hline
\end{tabular}



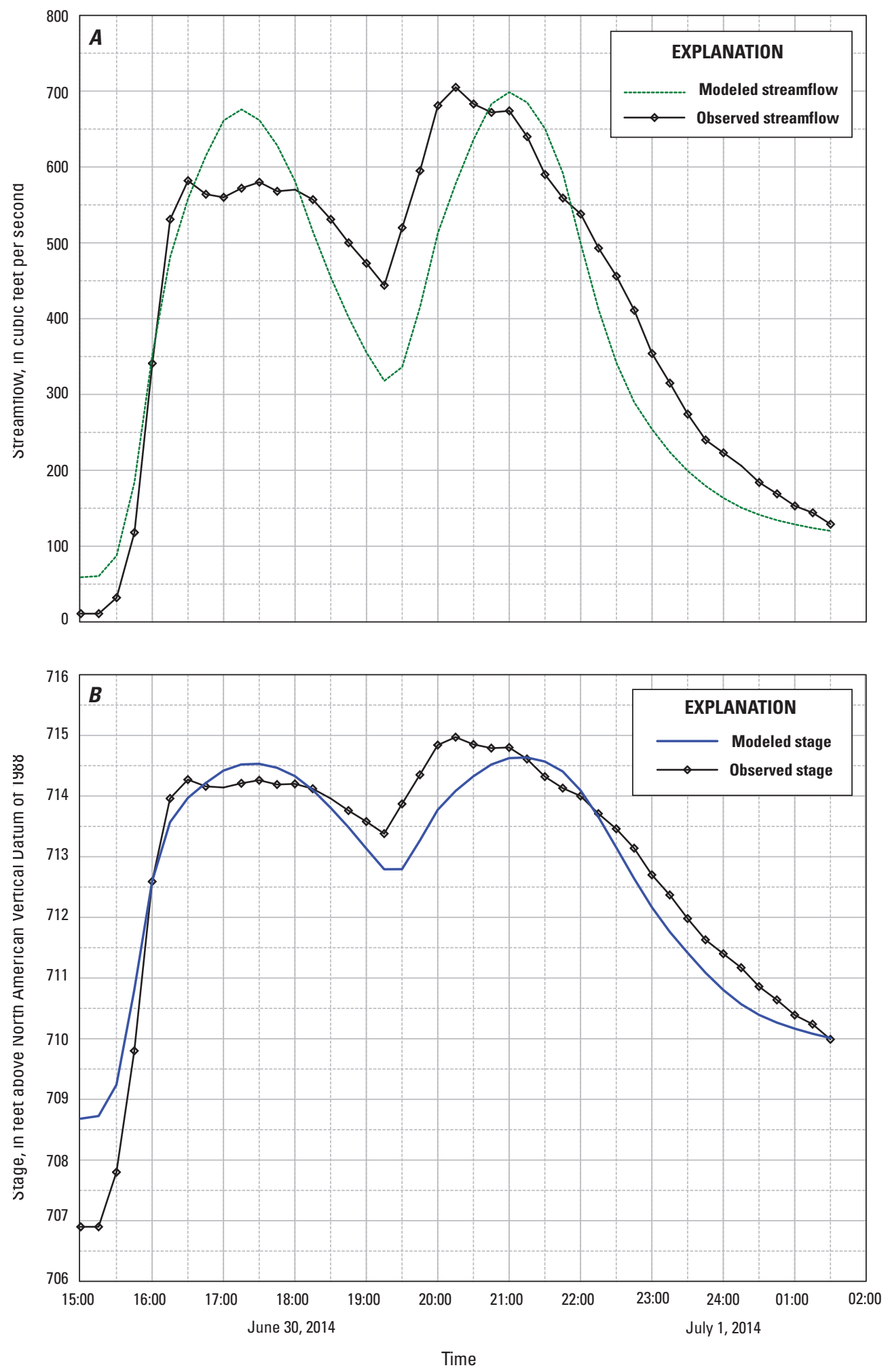

Figure 4. $A$, the relation between the hydraulic model outputs and observed streamflow and $B$, stage at the U.S. Geological Survey streamgage on Hoover Creek (05464942) during the June 30, 2014, flood event. 
Table 5. Observed and simulated peak streamflow, peak stage, and runoff volume from the U.S. Geological Survey streamgages $(05464942,0546494170)$ and the hydraulic model for the three historic rainfall events used to calibrate the hydrologic and hydraulic models of the Wapsinonoc Creek watershed.

[ USGS, U.S. Geological Survey; ft³/s, cubic feet per second; ft, feet; acre-ft, acre-feet; \% diff, percent difference equals (|observed - simulated//observed)*100; diff, difference equals simulated minus observed]

\begin{tabular}{|c|c|c|c|c|c|c|c|c|c|c|}
\hline \multirow{2}{*}{$\begin{array}{c}\text { Rainfall } \\
\text { event } \\
\text { (month/day/ } \\
\text { year) }\end{array}$} & \multirow[t]{2}{*}{$\begin{array}{c}\text { USGS } \\
\text { station number }\end{array}$} & \multicolumn{3}{|c|}{$\begin{array}{l}\text { Peak streamflow } \\
\qquad\left(\mathrm{ft}^{3} / \mathbf{s}\right)\end{array}$} & \multicolumn{3}{|c|}{$\begin{array}{l}\text { Peak stage } \\
\text { (ft) }\end{array}$} & \multicolumn{3}{|c|}{$\begin{array}{l}\text { Runoff volume } \\
\text { (acre-ft) }\end{array}$} \\
\hline & & Observed & Simulated & $\%$ diff & Observed & Simulated & diff & Observed & Simulated & $\%$ diff \\
\hline $06 / 30 / 2014$ & 05464942 & 705 & 699 & 0.85 & 714.97 & 714.63 & -0.34 & 373.62 & 345.26 & 7.59 \\
\hline $07 / 12 / 2014$ & 05464942 & 546 & 557 & 2.01 & 714.05 & 714.04 & -0.01 & 217.25 & 222.51 & 2.36 \\
\hline $06 / 15 / 2015$ & 05464942 & 329 & 355 & 7.90 & 712.49 & 712.83 & 0.34 & 92.93 & 91.34 & 1.71 \\
\hline $06 / 15 / 2015$ & 0546494170 & 524 & 587 & 12.02 & 709.52 & 709.97 & 0.45 & 167.29 & 172.73 & 3.25 \\
\hline
\end{tabular}

that evening, producing the high runoff conditions that were observed from this event.

This storm system produced isolated heavy rain cells, so NEXRAD MPE hourly precipitation data were used to provide better spatial resolution of rainfall distribution within the watershed. The Rapid Creek precipitation gage (414345091253801) received heavy rainfall totaling 4.5 in. from this event, which would have resulted in overestimation of precipitation runoff if this total had been applied to the entire study area. The simulated stage and streamflow hydrographs from the models corresponded with the observed hydrographs from the Hoover Creek streamgage (05464942), which were the only available data for calibration of this event (fig. 5). The simulated streamflow hydrograph had a crest within $11 \mathrm{ft}^{3} / \mathrm{s}$ of the observed hydrograph, and the simulated stage hydrograph had a crest within $0.01 \mathrm{ft}$ of the observed hydrograph (table 5).

\section{June 15, 2015, Event}

The June 15, 2015, event produced bankfull conditions for the Wapsinonoc and Hoover Creeks with some flooding of lowland areas upstream from the city of West Branch. Even though this was an event of smaller magnitude, it was chosen for model calibration because all four USGS streamgages (05464942, 0546494170, 0546494140, 0546494150) and both USGS precipitation gages (414209091215801, 414208091204701) located within the study area captured this event. The watershed received approximately 2 in. of rainfall with 0.3 to $0.4 \mathrm{in}$. of precipitation occurring in the morning and 1.5 to 1.6 in. of more intense rainfall occurring in the afternoon.

From this event, the Hoover Creek streamgage (05464942) and Wapsinonoc Creek streamgage (0546494170) recorded peak streamflows of 329 and $524 \mathrm{ft}^{3} / \mathrm{s}$, respectively. Small secondary peaks from the observed hydrographs of these two streamgages $(05464942,0546494170)$ were not depicted in the simulated hydrographs (figs. 6 and 7). These small peaks were the result of a 15 -minute lull from the storm's activity between two short durations of intense rainfall. Modeling techniques were not able to replicate the same resolution and concentrated the precipitation runoff into single peaking hydrographs, which produced slightly higher values than what was observed. However, runoff volumes from the simulated and observed hydrographs agreed with simulated runoff volume of 91.34 acre-foot (acre-ft) compared to the observed 92.93 acre- $\mathrm{ft}$ at the Hoover Creek streamgage (05464942) and a simulated runoff volume of 172.73 acre-ft compared to the observed 167.29 acre-ft at the Wapsinonoc Creek streamgage (0546494170) (table 5).

The stage-only streamgages $(0546494140,0546494150)$ were only used for the timing of peak flows in model calibration, because the magnitude of the event was too small to use stage hydrographs from the stage-only streamgages for model calibration. The stage associated with the minimum flows that were needed to keep the HEC-RAS model stable during the beginning of the simulation were only 1.25 to $2.25 \mathrm{ft}$ below the observed peak of the two stage-only streamgages (0546494140, 0546494150), the values of which rose more than $4 \mathrm{ft}$ during the event. These minimum flows meant there was less channel capacity for the initial surge in streamflow, so the simulated stages from the HEC-RAS model were overestimated at these locations.

\section{Model Evaluation}

The observed and simulated data at the streamgages used in calibration for the three historic rainfall events are presented in table 5. In general, the model results compared well with the observed data, and some marginal discrepancies can be explained. Due to insufficient precipitation data from within the study area, the second peak in the simulated hydrograph from the June 30, 2014, event is underestimated (fig. 4). The underestimation is why there are lower simulated 

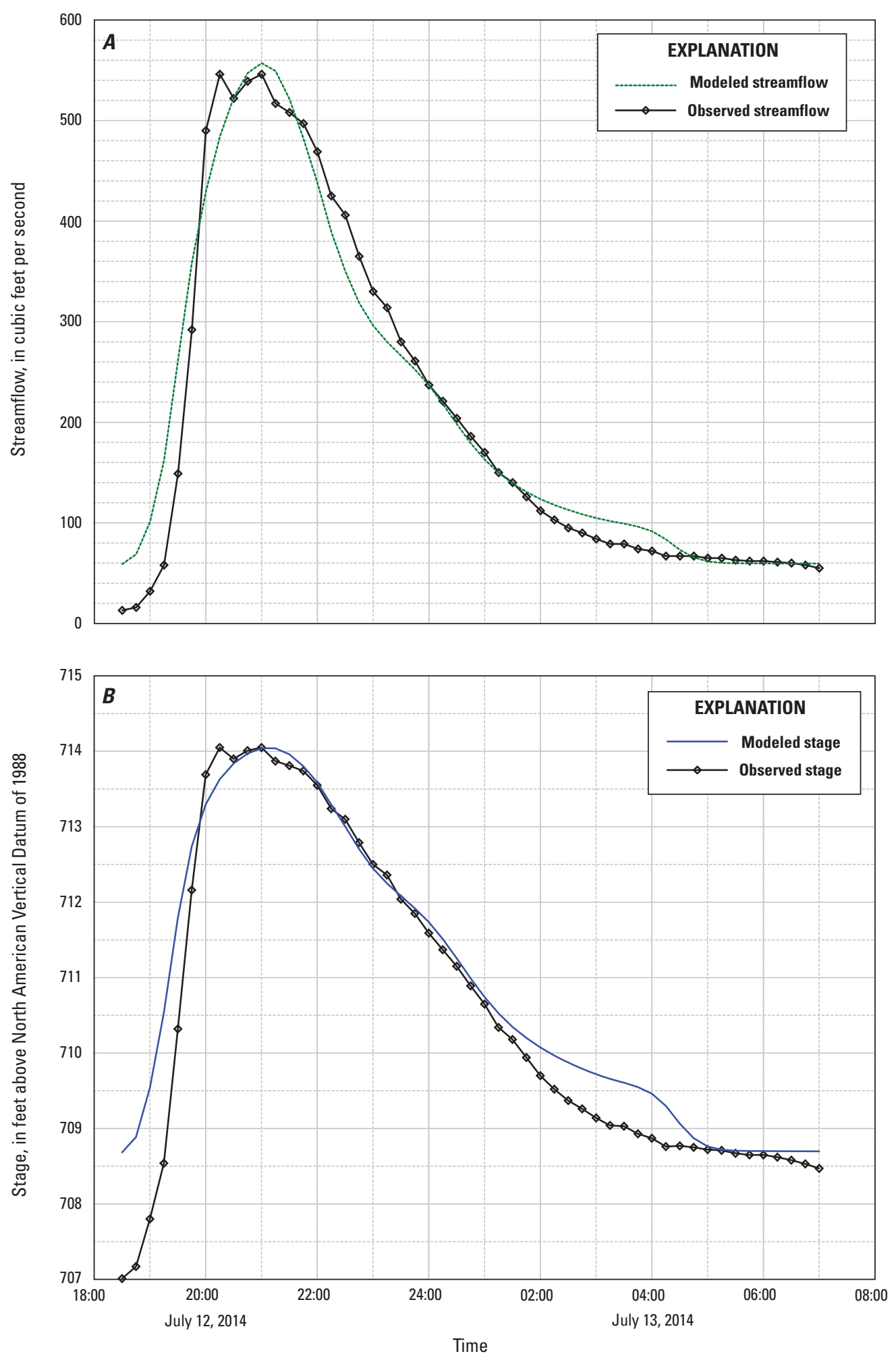

Figure 5. $A$, the relation between the hydraulic model outputs and observed streamflow and $B$, stage at the U.S. Geological Survey streamgage on Hoover Creek (05464942) during the July 12, 2014, flood event. 

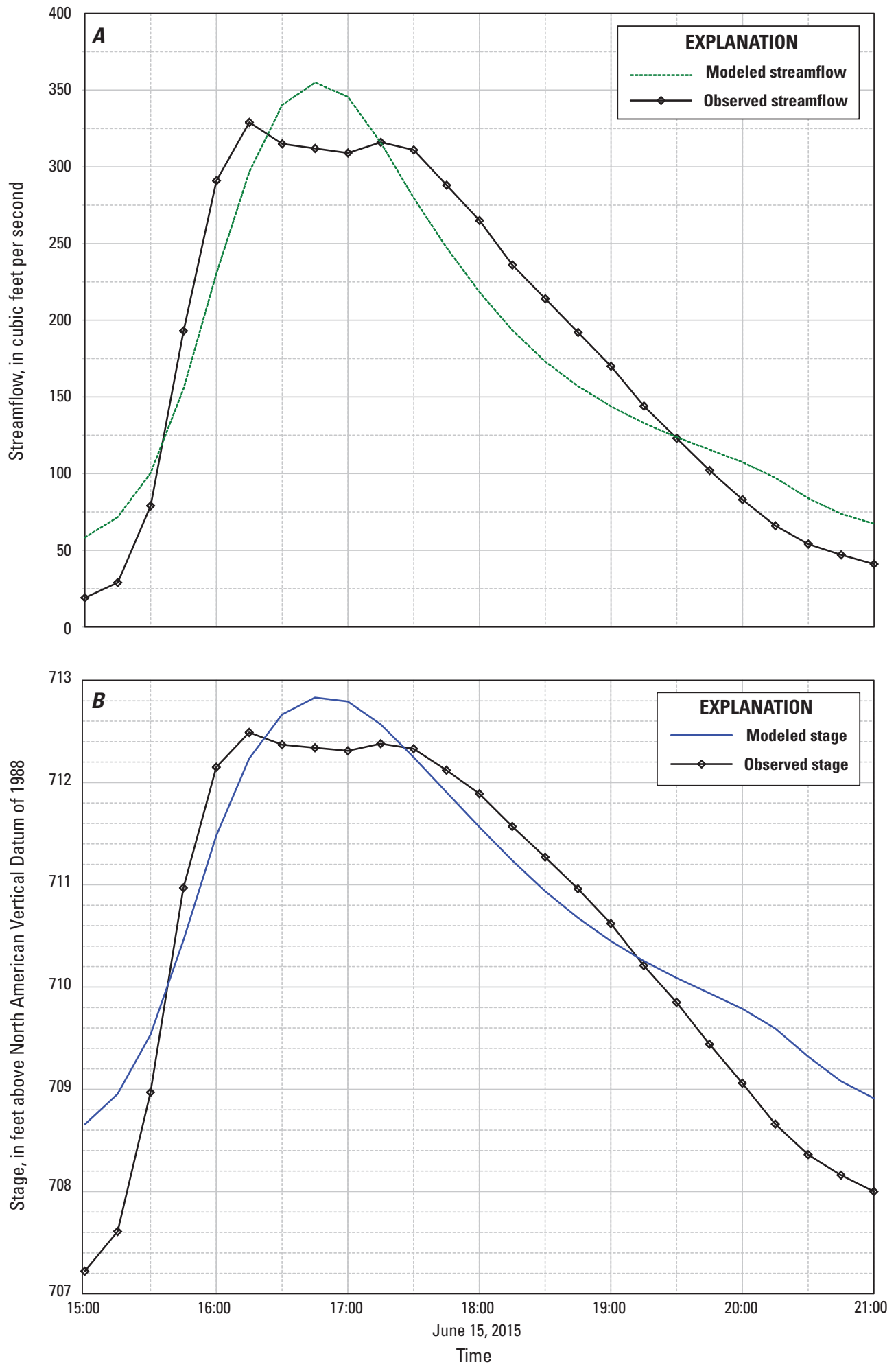

Figure 6. A, the relation between the hydraulic model outputs and observed streamflow and $B$, stage at the U.S. Geological Survey streamgage on Hoover Creek (05464942) during the June 15, 2015, high-water event. 

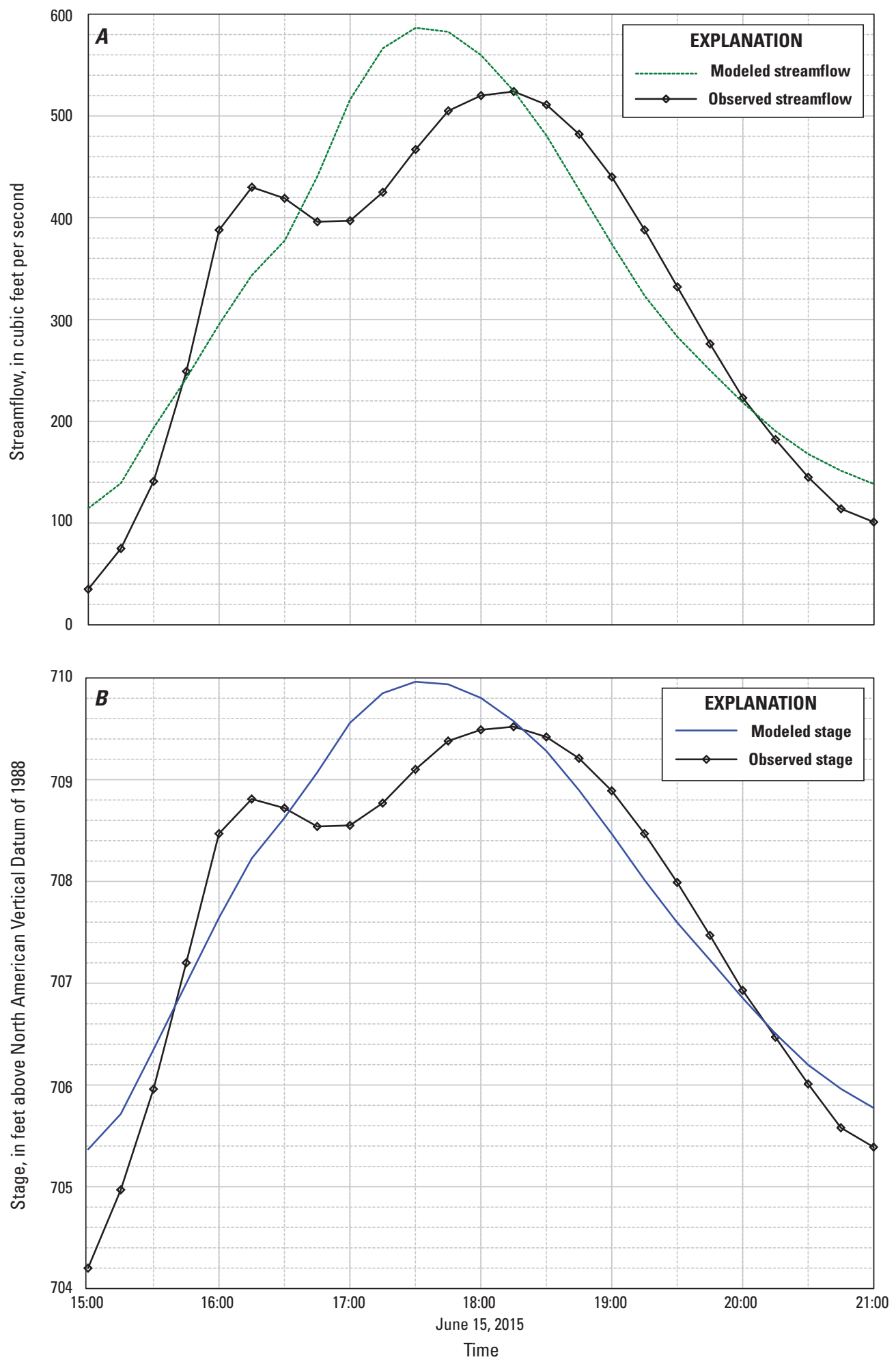

Figure 7. $A$, the relation between the hydraulic model outputs and observed streamflow and $B$, stage at the U.S. Geological Survey streamgage on Wapsinonoc Creek (0546494170) during the June 15, 2015, high-water event. 
values of peak stage and runoff volume for this event. The slightly larger simulated peak flows and stages from the June 15,2015 , event resulted because the model concentrated the precipitation runoff into one single-peaking hydrograph, but the modeling results still accurately depict the runoff volumes for this event.

The Nash-Sutcliffe efficiency (NSE) statistic and percent bias (PBIAS) were calculated with the model outputs and observed hydrographs from the streamgages ( 05464942 , 0546494170) used to calibrate the models (table 6). The NSE is a normalized statistic that provides a measure of how well simulated values match measured datasets (Nash and Sutcliffe, 1970). NSE values range from - $\infty$ to 1 . Values of less than 0 indicate that the mean measured streamflow is a better predictor than simulated streamflows. A value of 0.0 indicates the simulated streamflow is as good a predictor as using the average value of all the measured data, and a value of 1 indicates a perfect fit between measured and simulated values. The PBIAS measures the average tendency of the

Table 6. Nash-Sutcliffe efficiency and percent bias statistic values at U.S. Geological Survey streamgages (05464942, 0546494170) used to calibrate the hydrologic and hydraulic models of the Wapsinonoc Creek watershed.

[USGS, U.S. Geological Survey; NSE, Nash-Sutcliffe efficiency; PBIAS, percent bias]

\begin{tabular}{rrrr}
$\begin{array}{c}\text { Rainfall event } \\
\text { (month/day/year) }\end{array}$ & $\begin{array}{c}\text { USGS station } \\
\text { number }\end{array}$ & NSE & PBIAS \\
Calibrated to stage-elevation hydrographs & \\
\hline $06 / 30 / 2014$ & 05464942 & 0.91 & 0.01 \\
$07 / 12 / 2014$ & 05464942 & 0.93 & -0.05 \\
$06 / 15 / 2015$ & 05464942 & 0.86 & -0.04 \\
$06 / 15 / 2015$ & 0546494170 & 0.87 & -0.02 \\
\hline Calibrated to streamflow hydrographs & \\
$06 / 30 / 2014$ & 05464942 & 0.86 & 6.63 \\
$07 / 12 / 2014$ & 05464942 & 0.98 & -2.64 \\
$06 / 15 / 2015$ & 05464942 & 0.90 & 0.99 \\
$06 / 15 / 2015$ & 0546494170 & 0.82 & -3.92 \\
\hline
\end{tabular}

simulated data to be larger or smaller than their observed data (Gupta and others, 1999). The optimal value of PBIAS is 0.0, with low-magnitude values indicating accurate model simulation. Positive values indicate model underestimation bias, and negative values indicate model overestimation bias (Gupta and others, 1999).

The calculated values of all the statistical parameters were well within the values recommended by Moriasi and others (2007) for an NSE $>0.50$ and a PBIAS of $+/-25$ percent. Table 6 lists all of the NSE and PBIAS values by streamgage within the model. The NSE for stage calibration ranged from 0.87 to 0.91 , and the NSE for streamflow calibration ranged from 0.82 to 0.98 . The PBIAS for stage calibration ranged from -0.05 to 0.01 , and the PBIAS for streamflow calibration ranged from -3.92 to 6.63 . These results indicate a very good performance rating for model calibration.

\section{Existing-Conditions Model With Frequency Storms}

An existing conditions HEC-RAS model was built and run with HEC-HMS outputs from design rainfall events in order to provide a baseline for comparison of the floodmitigation scenarios.

\section{HEC-HMS Model and Design Rainfall Events}

The HEC-HMS model was incorporated with design rainfall events in order to simulate a range of intense precipitation runoff values. In order to develop design rainfall events, statistical precipitation data from the National Oceanic and Atmospheric Administration was used to provide precipitation-frequency estimates within the study area (Perica and others, 2013). The precipitation-frequency estimates were for

Table 7. National Oceanic and Atmospheric Administration (NOAA) Atlas 14 precipitation-frequency estimates of 24-hour rainfall duration from the partial duration series for the Wapsinonoc Creek watershed (Perica and others, 2013).

[in, inches; \%, percent; AEP, annual exceedance probability]

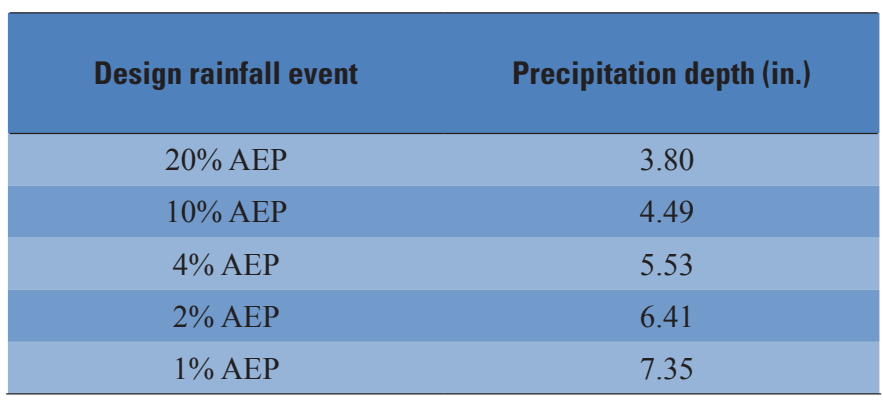

20-, 10-, 4-, 2-, and 1-percent annual exceedance probabilities (AEPs) for a 24-hour rainfall duration from the partial duration series (table 7). An intensity duration of 15 minutes was used to represent the period of time for the most intense rainfall during a design rainfall event. Once the frequency rainfall data were applied to the HEC-HMS model, a HEC-HMS basin model was designed to represent the average hydrologic conditions within the Wapsinonoc Creek watershed. 
During the HEC-HMS calibration of the historic rainfall events, SCS CNs and Clark unit-hydrograph $T_{\mathrm{c}}$ values were the only modeling parameters that were varied. SCS $C N(I I)$ values were used for modeling design rainfall events because they represent average antecedent runoff conditions and are primarily used for design applications (SCS, 1986). Clark unit-hydrograph $T_{\mathrm{c}}$ values were averaged from the three calibration events, and the remaining HEC-HMS parameters did not need to be adjusted because they stayed constant for the model calibration of historic rainfall events. A basin model was then created in HEC-HMS with the averaged parameters and SCS CN(II) values for the 20-, 10-, 4-, 2-, and 1-percent AEP design rainfall events.

\section{HEC-RAS Existing Conditions}

The calibrated HEC-RAS model was used to represent the existing conditions, which include present-day stream channel geometries, flood-plain development, hydraulic structures, and land cover. The HEC-RAS existing conditions were used to simulate flood profiles for the 20-, 10-, 4-, 2-, and 1-percent AEP design rainfall events. In order to assess the magnitude of streamflow from these design rainfall events, the simulated peak streamflows at the Hoover Creek streamgage (05464942) were evaluated under existing conditions (table 8). A comparison showed that the peak streamflow of $720 \mathrm{ft}^{3} / \mathrm{s}$ from the 20-percent AEP frequency storm was very close to the $705 \mathrm{ft}^{3} / \mathrm{s}$ peak streamflow from the June 30, 2014, flooding event. The peak streamflow of $1,646 \mathrm{ft}^{3} / \mathrm{s}$ from the 1 -percent AEP frequency storm also compares well to the estimated $1,650 \mathrm{ft}^{3} / \mathrm{s}$ peak streamflow from the August 16, 1993, flooding event.

Table 8. Peak streamflows from the design rainfall events with the existing conditions hydraulic model at the Hoover Creek U.S. Geological Survey streamgage (05464942) located at the Herbert Hoover National Historic Site.

$\left[\mathrm{ft}^{3} / \mathrm{s}\right.$, cubic feet per second; $\%$, percent; AEP, annual exceedance probability]

Design rainfall event

Peak streamflow $\left(\mathrm{ft}^{3} / \mathrm{s}\right)$

$20 \%$ AEP

720

$10 \%$ AEP

899

$4 \%$ AEP

1,133

$2 \%$ AEP

1,367

$1 \%$ AEP

1,646

\section{Flood-Mitigation Scenarios}

Flood-mitigation scenarios were simulated with the HEC-RAS model. The scenarios model attenuating streamflows with the use of detention structures upstream from the city of West Branch and improving the conveyance of overbank flows through the city by removing flow restrictions.

\section{Streamflow Attenuation}

In 2012, the city of West Branch built an in-channel detention basin on Hoover Creek with approximately 45 acre-ft of storage (fig. 8) (Norfleet, 2013), and the NPS is currently in the planning process for building an off-channel detention basin within HEHO. The city of West Branch is interested in the effects of in-channel detention basins for the Wapsinonoc Creek upstream from the city. Four proposed locations were chosen in consultation with the city of West Branch for the simulation of in-channel detention basins (fig. 8) for the flood-mitigation scenarios. The proposed inchannel detention basins were designed to meet the following criteria (table 9):

- drainage area not exceeding $1 \mathrm{mi}^{2}$,

- storage capacity not exceeding 50 acre-ft,

- dam height not exceeding $10 \mathrm{ft}$ in height from the stream banks, and

- outlet culvert with at least 1-percent slope.

During the existing conditions simulations, the Hoover Creek in-channel detention basin reached storage capacity during the 4-percent AEP design rainfall event, so the proposed in-channel detention basins were designed to contain the 10-percent AEP design rainfall event. The two larger in-channel detention basins needed their outflow outlets to be outfitted with a $3.5 \mathrm{ft}$-diameter culvert to have the carrying capacity for the 10-percent AEP design rainfall event. The two smaller in-channel detention basins have the capacity to hold back the 1-percent AEP design rainfall event with a $1.5 \mathrm{ft}$-diameter culvert as the outflow outlet because they have a relatively small drainage areas.

\section{Conveyance Improvement}

Downstream from the Hoover Creek and Wapsinonoc Creek confluence, there is an abandoned railroad embankment, which constricts the flood plain on the southeast edge of the city of West Branch (fig. 9). This area causes a backwater effect during flash floods even though the railroad bridge deck, piers, and the bridge abutment on the south side were removed in the 1990s, (D. Schechinger, oral commun., 2016). An additional 120-ft section of the railroad embankment was removed from the right bank side (looking downstream) and bench cut down to an elevation of $705 \mathrm{ft}$ at the top of the stream bank (fig. 10) in the HEC-RAS model. There is also an old truss bridge $400 \mathrm{ft}$ downstream from the abandoned railroad 


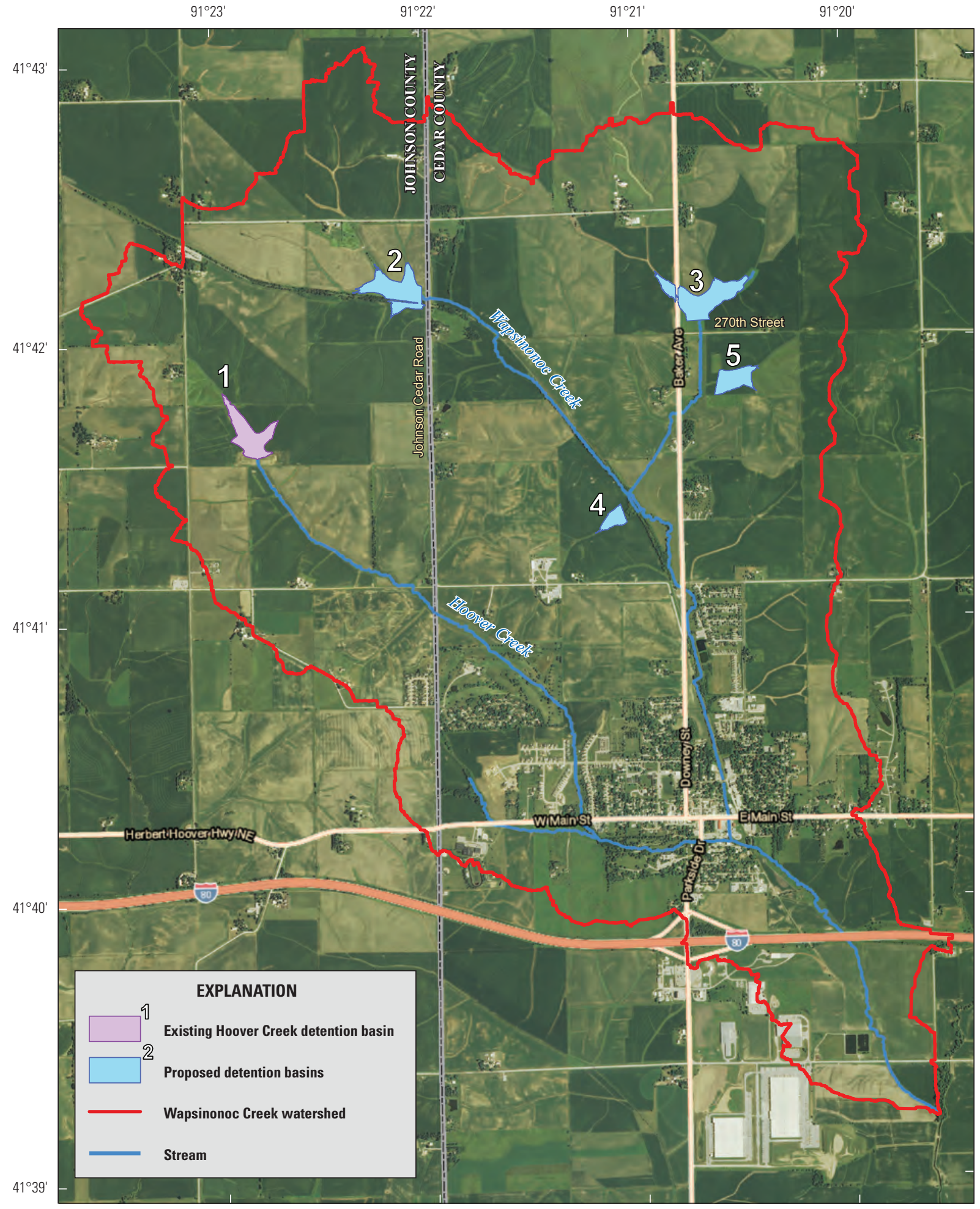

Universal Transverse Mercator projection Zone 15

Orthophotograph modified from Farm Services Administration, Horizontal coordinate information is referenced to the National Agriculture Imagery Program, 2013

North American Datum of 1983 (NAD 83)

1.5 MILES

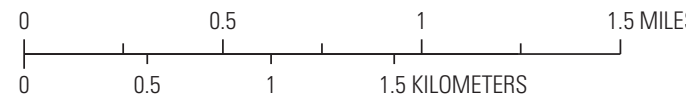

Figure 8. Locations of the existing and proposed in-channel detention structures in the Wapsinonoc Creek watershed. 
Table 9. Proposed and existing in-channel detention structures with their associated drainage area, storage capacity, dam height, and outlet culvert size.

$\left[\mathrm{mi}^{2}\right.$, square miles; acre-ft, acre-feet; $\mathrm{ft}$, feet $]$

\begin{tabular}{clcccc}
$\begin{array}{c}\text { Map number } \\
\text { (fig. 8) }\end{array}$ & \multicolumn{1}{c}{ Structure } & $\begin{array}{c}\text { Drainage area } \\
\left(\mathbf{m i}^{2}\right)\end{array}$ & $\begin{array}{c}\text { Storage capacity } \\
\text { (acre-ft) }\end{array}$ & $\begin{array}{c}\text { Dam height } \\
\text { (ft) }\end{array}$ & $\begin{array}{c}\text { Outlet culvert } \\
\text { diameter } \\
\text { (ft) }\end{array}$ \\
\hline 1 & Hoover Creek & 0.50 & 44.36 & 15 & 2.5 \\
2 & Johnson/Cedar Road & 0.71 & 49.71 & 10 & 3.5 \\
\hline 3 & 270th Street & 0.86 & 49.56 & 10 & 3.5 \\
4 & West of Baker Avenue & 0.15 & 16.44 & 10 & 1.5 \\
5 & East of Baker Avenue & 0.26 & 36.95 & 10 & 1.5 \\
\hline
\end{tabular}

embankment that is no longer used by the city of West Branch. The HEC-RAS model simulated the effects of removing a portion of the railroad embankment and the old truss bridge in order to improve the conveyance of the stream.

\section{Flood-Mitigation Modeling Results}

The flood-mitigation modeling was grouped into three scenarios: detention storage with temporary storage from detention structures attenuating peak streamflows, improved conveyance with the removal of a section of railroad embankment and the truss bridge, and the detention and conveyance scenarios combined. The water-surface profiles for the three scenarios were then plotted with the water-surface profiles for existing conditions so their flood-mitigation effects could be analyzed (figs. 11-20). The water-surface profiles consist of three stream reaches that flow through the city of West Branch and HEHO (fig. 9). The stream reach Wapsinonoc Creek upstream from Hoover Creek starts approximately $1,100 \mathrm{ft}$ upstream from the College Street Bridge where the Wapsinonoc Creek begins to threaten the low-lying residential neighborhoods and continues to the Hoover Creek confluence. This reach also consists of the East Main Street Bridge and the West Branch fire station which is approximately $350 \mathrm{ft}$ upstream from the Hoover Creek confluence. The stream reach of Wapsinonoc Creek downstream from Hoover Creek starts at the Hoover Creek confluence and flows approximately 500 $\mathrm{ft}$ downstream from the truss bridge. This reach also consists of the abandoned railroad embankment approximately $400 \mathrm{ft}$ downstream from the Hoover Creek confluence. The stream reach of Hoover Creek starts approximately $200 \mathrm{ft}$ upstream from the pedestrian bridge located at the USGS Hoover Creek streamgage (05464942) within HEHO and flows downstream to the Wapsinonoc Creek confluence. The stream reach also consists of the Downey Street, Parkside Drive, and 2nd Street bridge locations.

Water-surface elevations of the three scenarios and existing conditions were also calculated for eight locations along the three stream reaches (table 10). These locations include the upstream sides of the College Street, East Main Street, Downey Street, Parkside Drive, and 2nd Street bridges (fig. 9). The other locations with WSEs are the West Branch fire station and immediately upstream and downstream from the abandoned railroad embankment (fig. 10).

The detention-storage scenario produced streamflow attenuation throughout the Wapsinonoc Creek. The areas closest to the source of the detention storage received the greatest benefit such as the upstream side of the College Street Bridge, where simulated decreases were from 0.47 to $1.29 \mathrm{ft}$ in lower WSEs. Other areas along the Wapsinonoc stream reaches such as the East Main Street Bridge, fire station, and upstream from the railroad embankment had moderate improvements of 0.30 to $0.92 \mathrm{ft}$ in lower WSEs. The upstream side of the $2 \mathrm{nd}$ Street Bridge had the most improvement of the Hoover stream reach, ranging from 0.19 to $0.64 \mathrm{ft}$ in lower WSEs because this area receives overbank flow from both the Wapsinonoc and Hoover Creeks. The upstream sides of the Downey Street and Parkside Drive Bridges saw little improvement, ranging from 0.00 to $0.09 \mathrm{ft}$, suggesting that the attenuation of the Wapsinonoc Creek streamflow has little effect upstream from the Parkside Drive Bridge.

The conveyance-improvement scenario had the greatest improvement in WSEs from the railroad embankment upstream to the Wapsinonoc and Hoover confluence, East Main Street Bridge, and 2nd Street Bridge, with lower WSEs ranging from 0.93 to $1.48 \mathrm{ft}$ on the upstream side of the railroad embankment, 0.21 to $0.62 \mathrm{ft}$ at the fire station, 0.24 to $0.58 \mathrm{ft}$ on the upstream side of the $2 \mathrm{nd}$ Street Bridge, and 0.20 to $0.54 \mathrm{ft}$ on the upstream side of the East Main Street Bridge. Much less improvement was seen further upstream from the railroad embankment, with lower WSEs ranging from 0.00 to $0.22 \mathrm{ft}$ on the upstream side of the College Street, Parkside Drive, and Downey Street bridges.

The detention and conveyance combined scenario produced the most improvement in decreasing WSEs along the Wapsinonoc and Hoover reaches. The values of WSEs on the upstream side of the railroad embankment ranged from 1.13 to $1.90 \mathrm{ft}$ in lower WSEs. The values of WSEs 


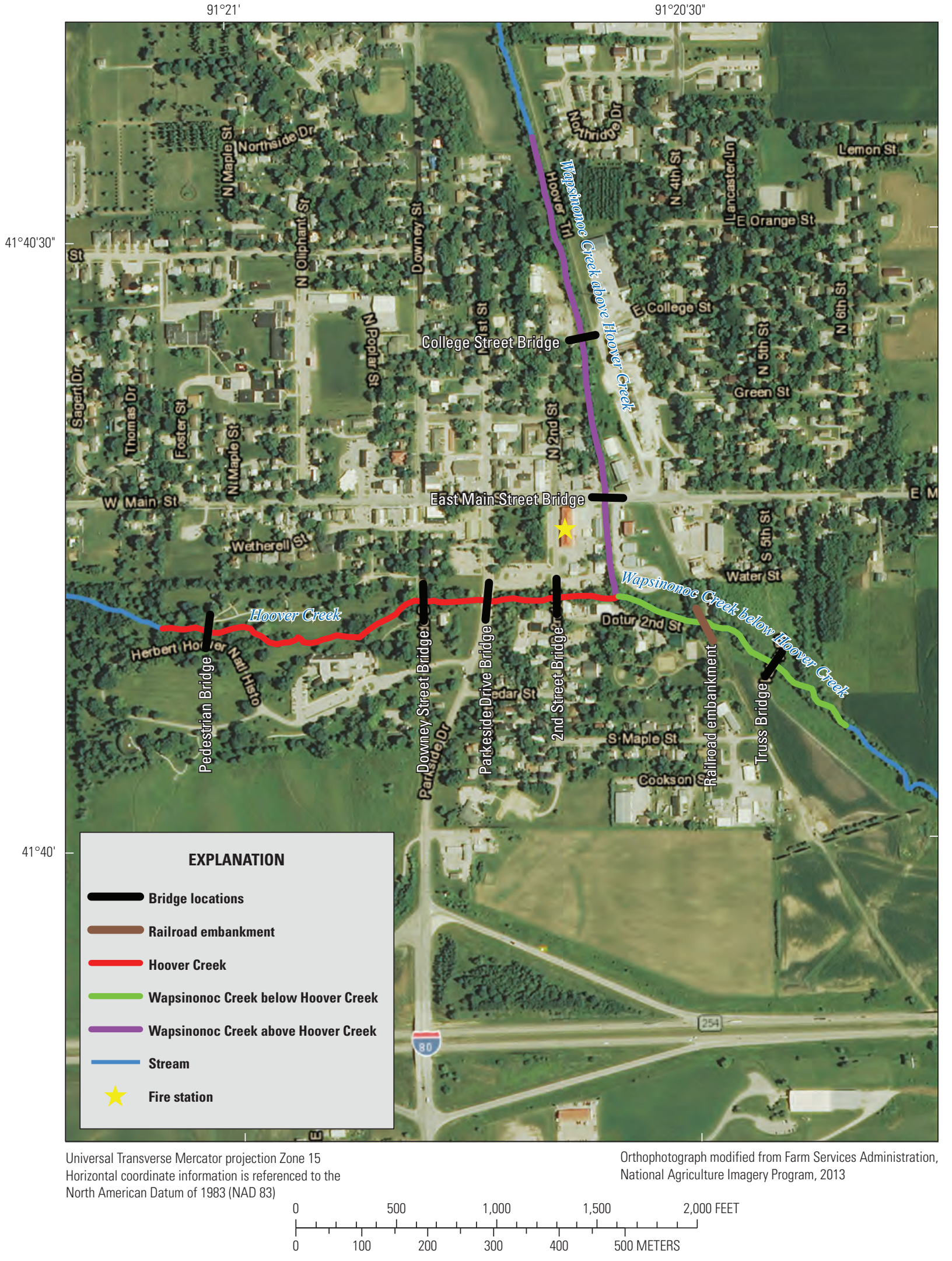

Figure 9. The three stream reaches and the locations of bridges, the railroad embankment, and the fire station for modeling the flood-mitigation scenarios. 


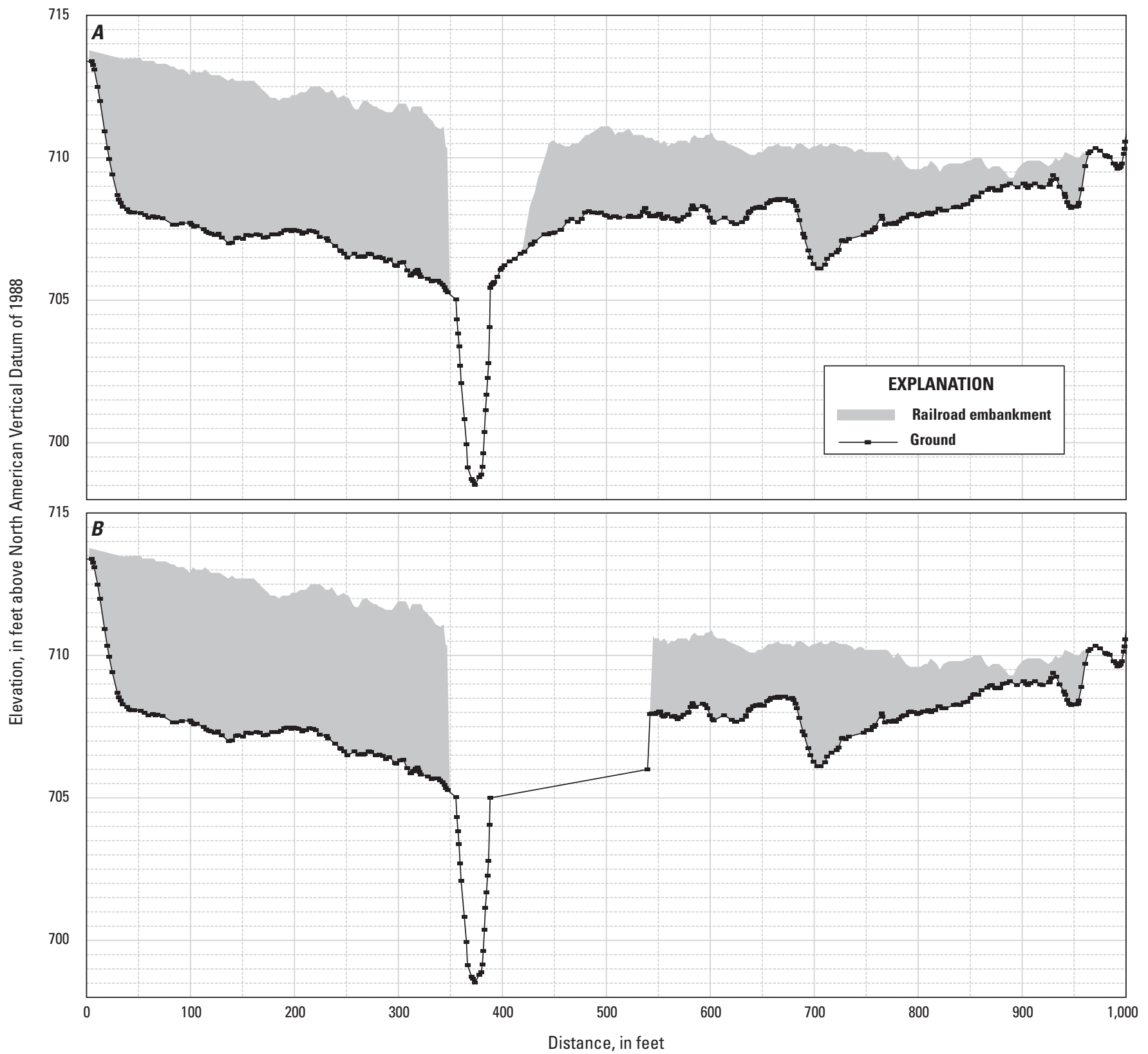

Figure 10. $A$, a cross section of the existing railroad embankment and $B$, the modifications made to improve conveyance through this structure. 
Flood-Mitigation Scenarios

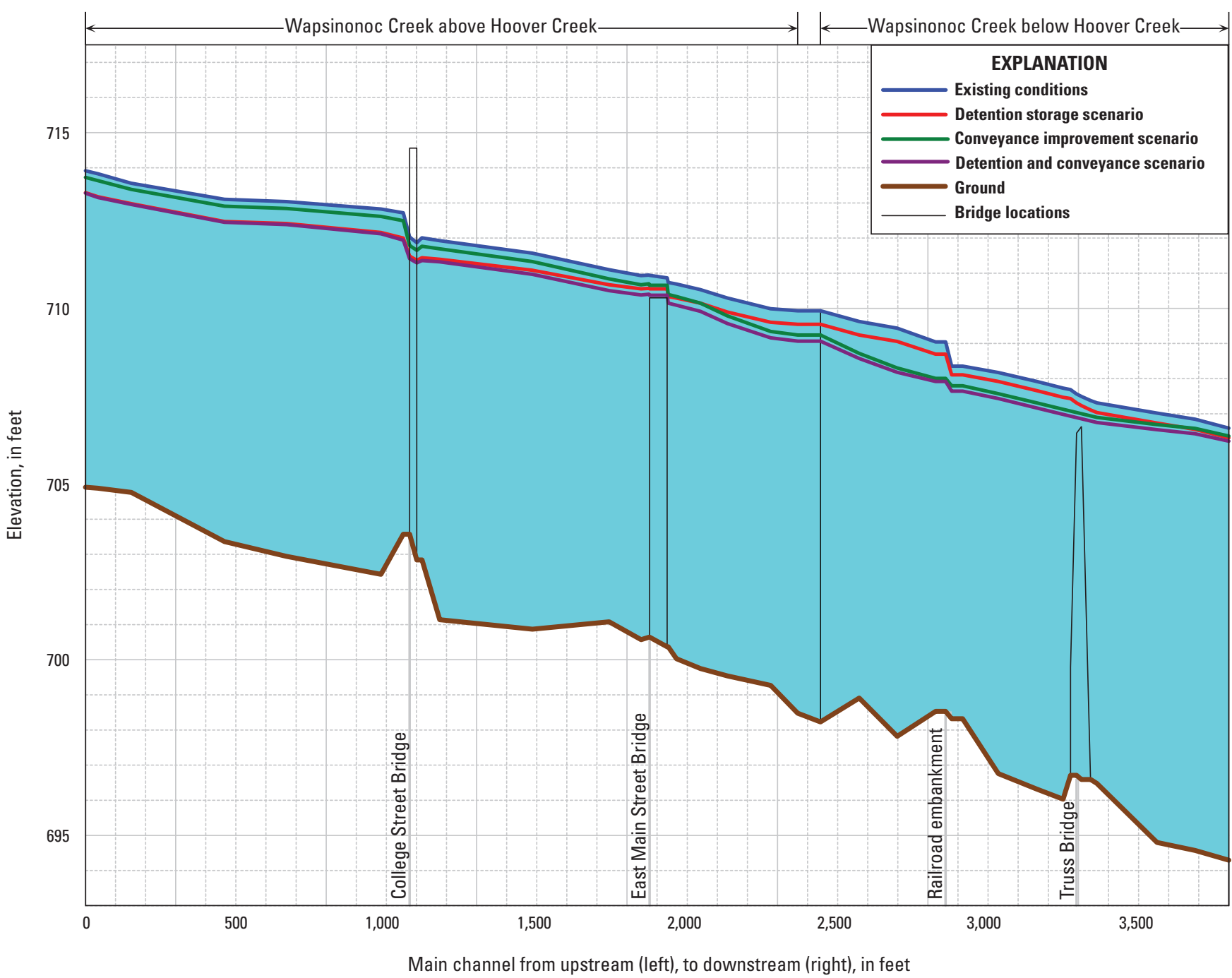

Figure 11. Results from simulation of a design rainfall event with 20-percent annual exceedance probability with the water-surface profiles of the Wapsinonoc Creek stream reaches. 


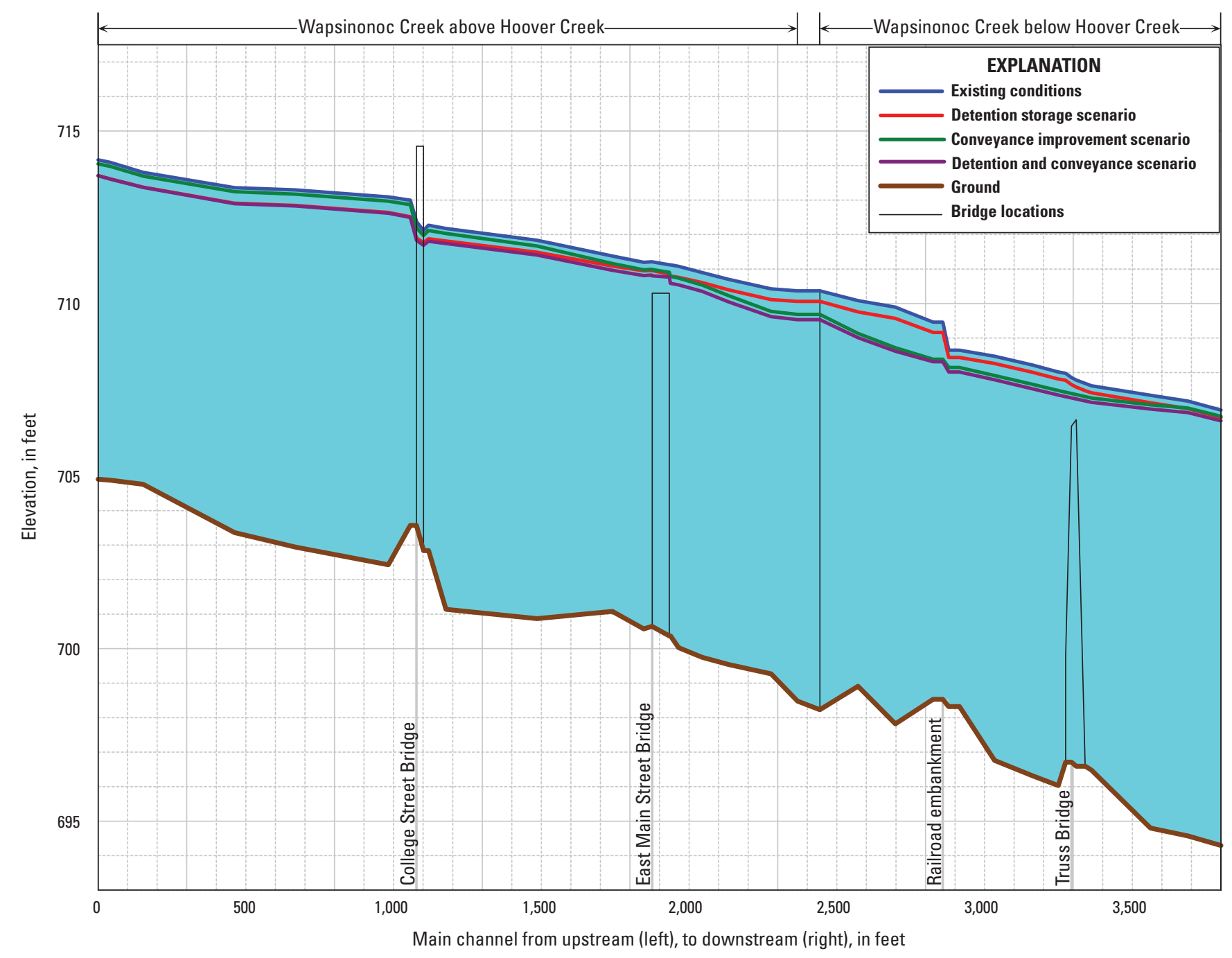

Figure 12. Results from simulation of a design rainfall event with 10-percent annual exceedance probability with the water-surface profiles of the Wapsinonoc Creek stream reaches. 
Flood-Mitigation Scenarios

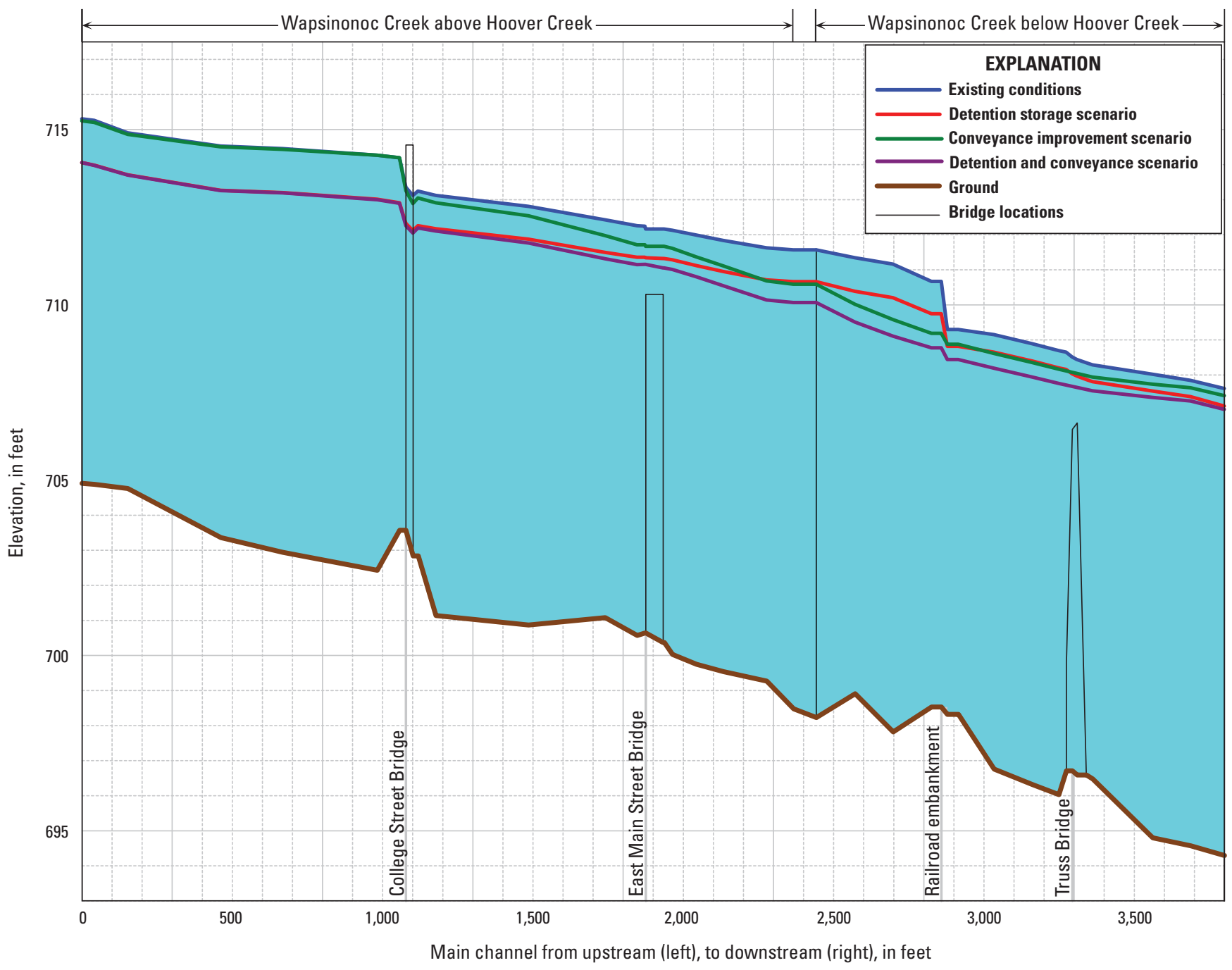

Figure 13. Results from simulation of a design rainfall event with 4-percent annual exceedance probability with the water-surface profiles of the Wapsinonoc Creek stream reaches. 


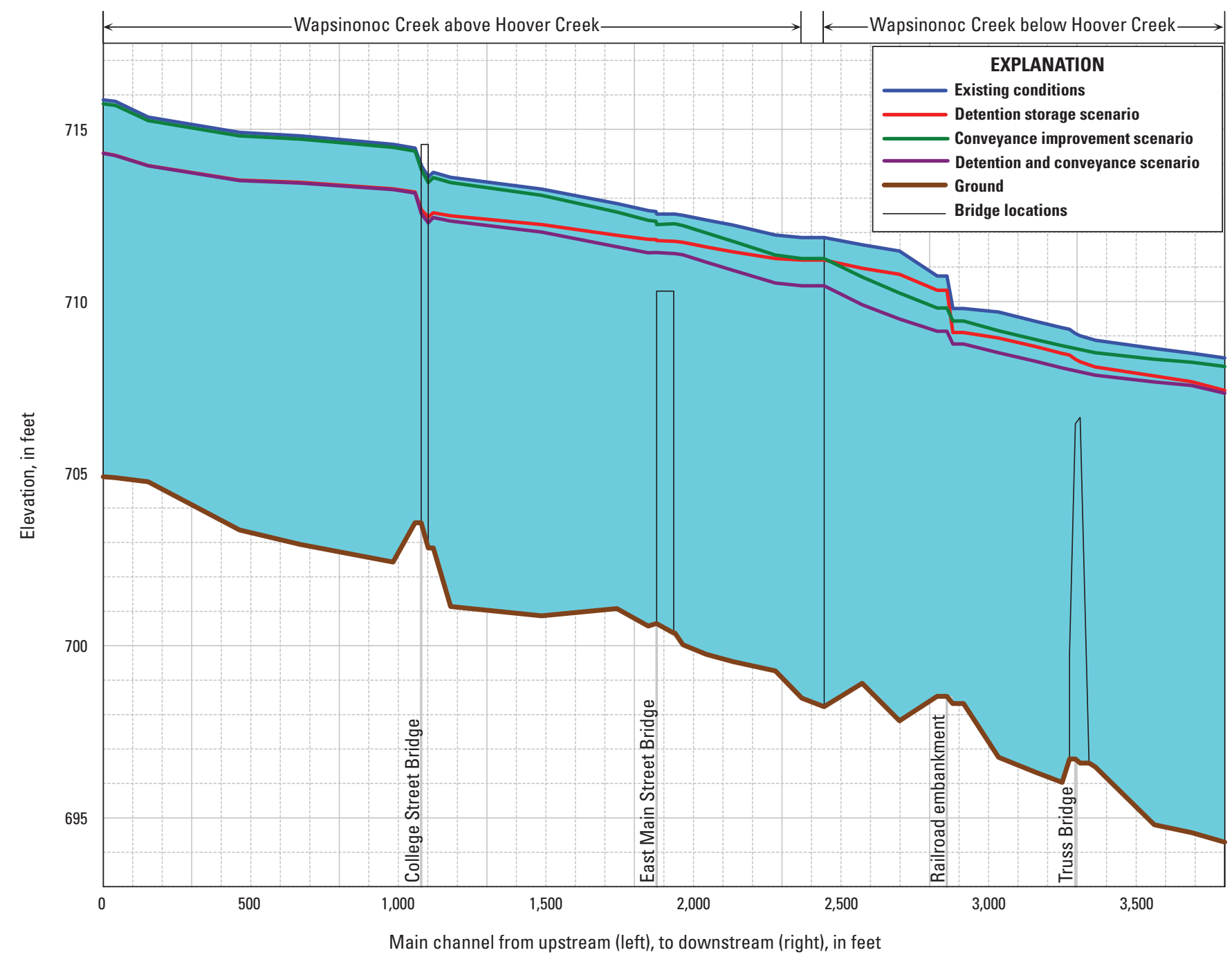

Figure 14. Results from simulation of a design rainfall event with 2-percent annual exceedance probability with the water-surface profiles of the Wapsinonoc Creek stream reaches. 


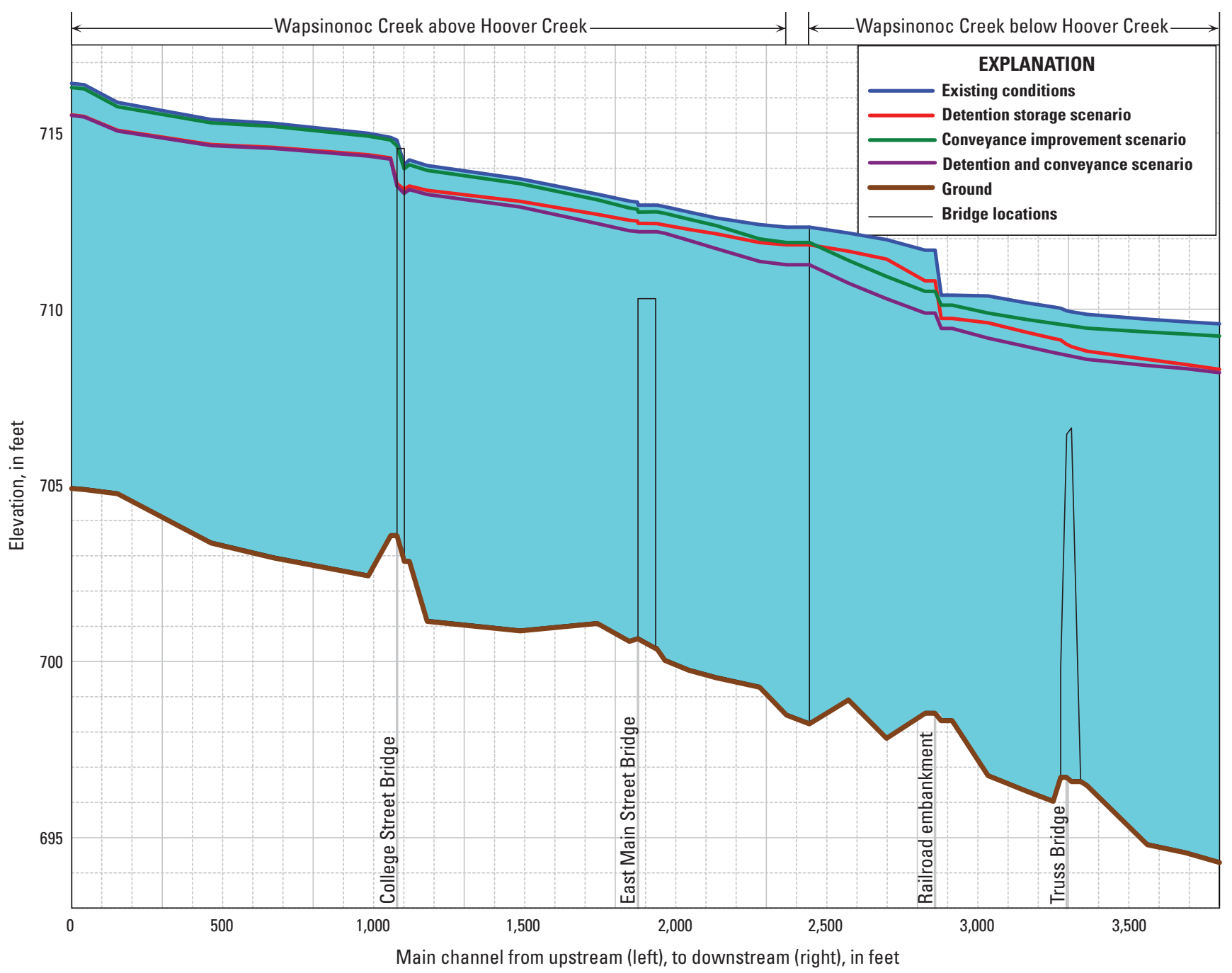

Figure 15. Results from simulation of a design rainfall event with 1-percent annual exceedance probability with the water-surface profiles of the Wapsinonoc Creek stream reaches. 


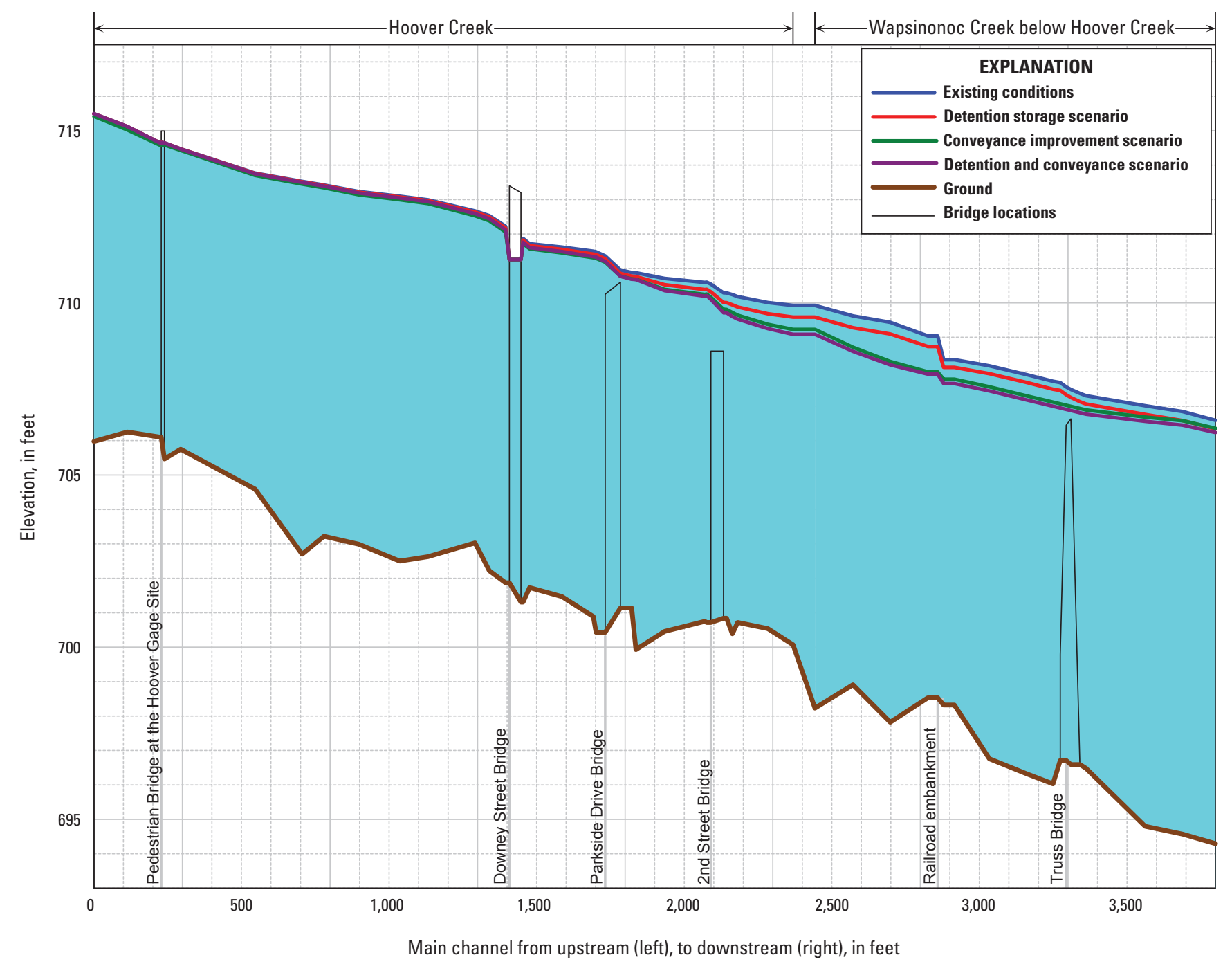

Figure 16. Results from simulation of a design rainfall event with 20-percent annual exceedance probability with water-surface profiles of Hoover Creek and Wapsinonoc Creek downstream from Hoover Creek. 


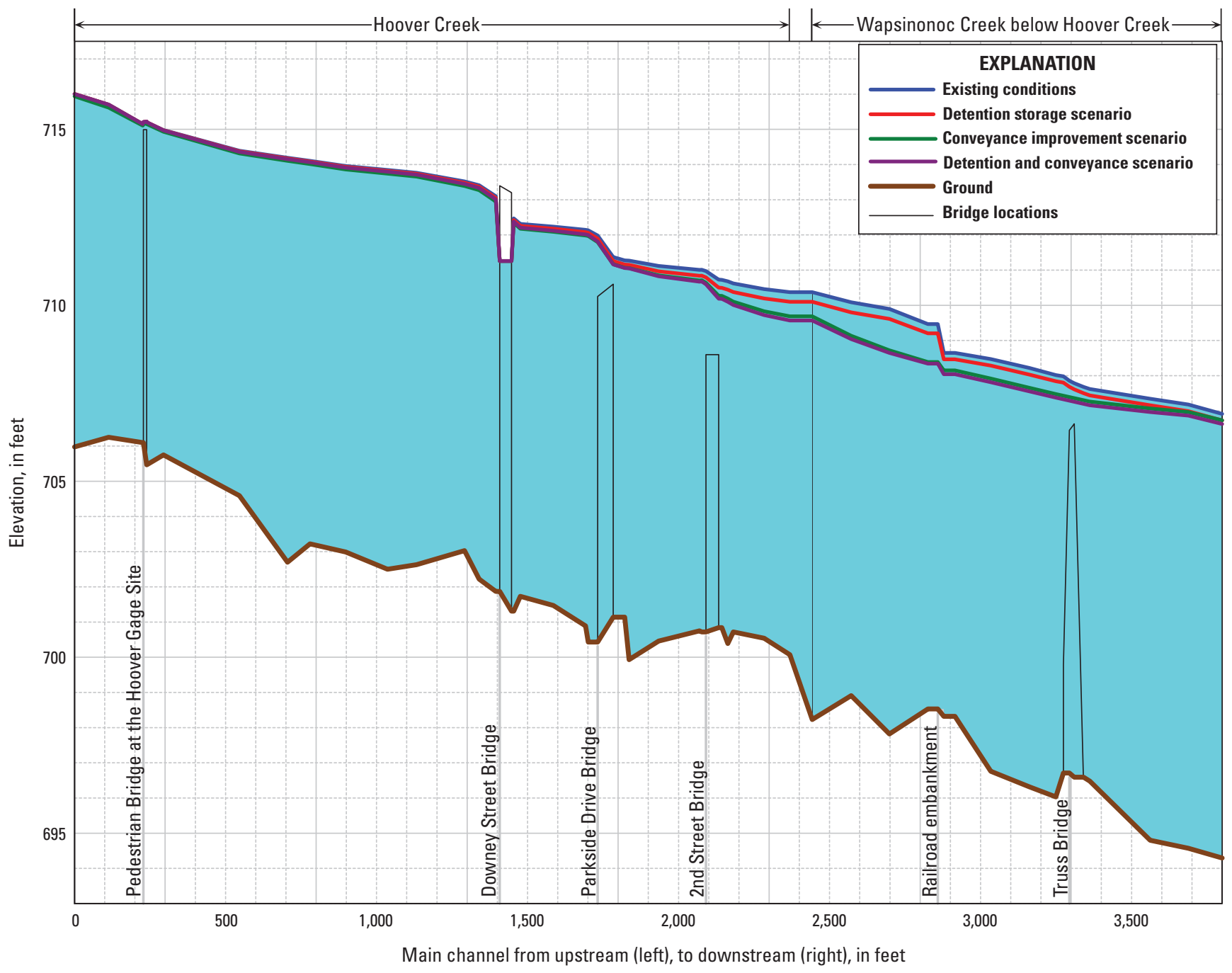

Figure 17. Results from simulation of a design rainfall event with 10-percent annual exceedance probability with water-surface profiles of Hoover Creek and Wapsinonoc Creek downstream from Hoover Creek. 


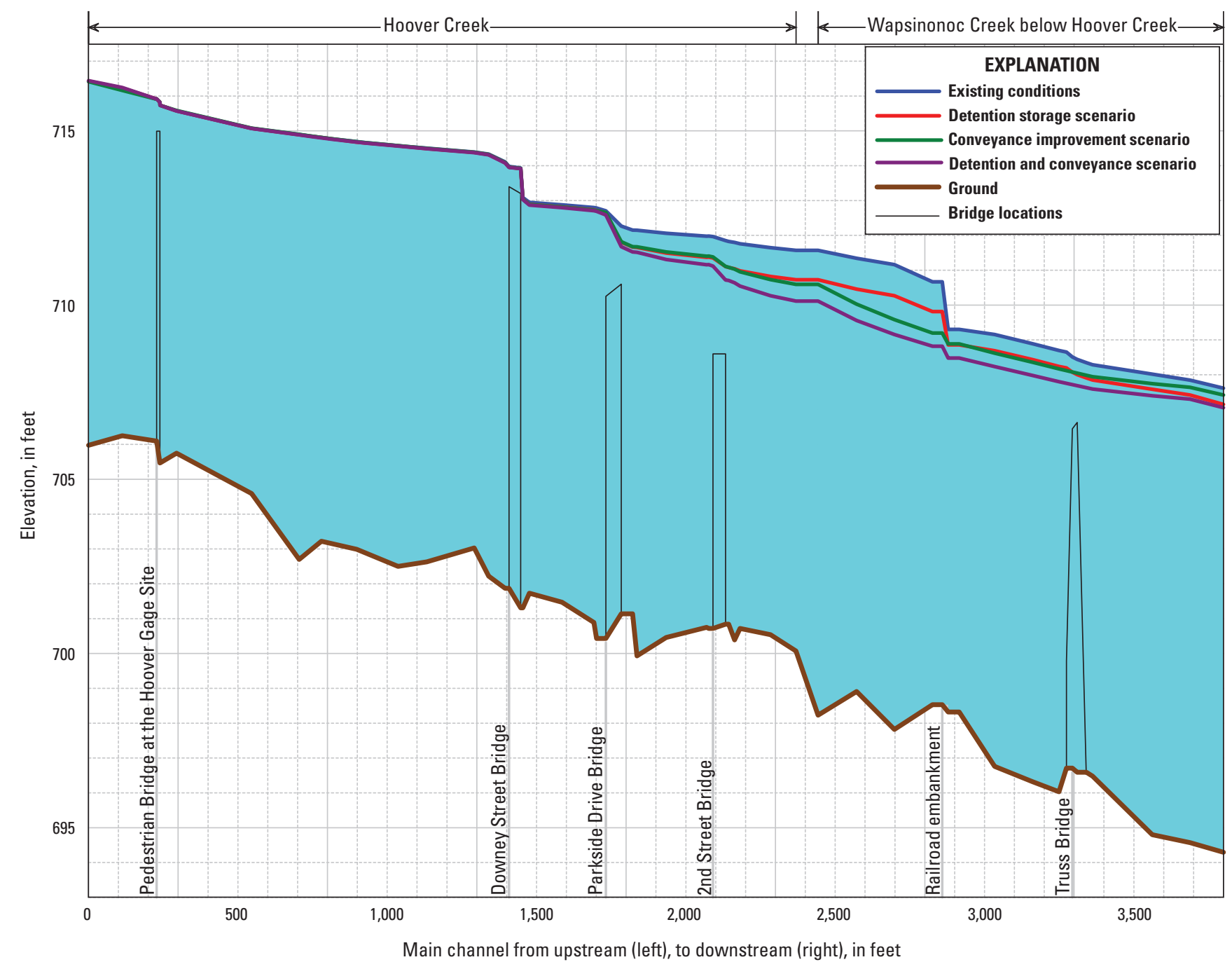

Figure 18. Results from simulation of a design rainfall event with 4-percent annual exceedance probability with water-surface profiles of Hoover Creek and Wapsinonoc Creek downstream from Hoover Creek. 


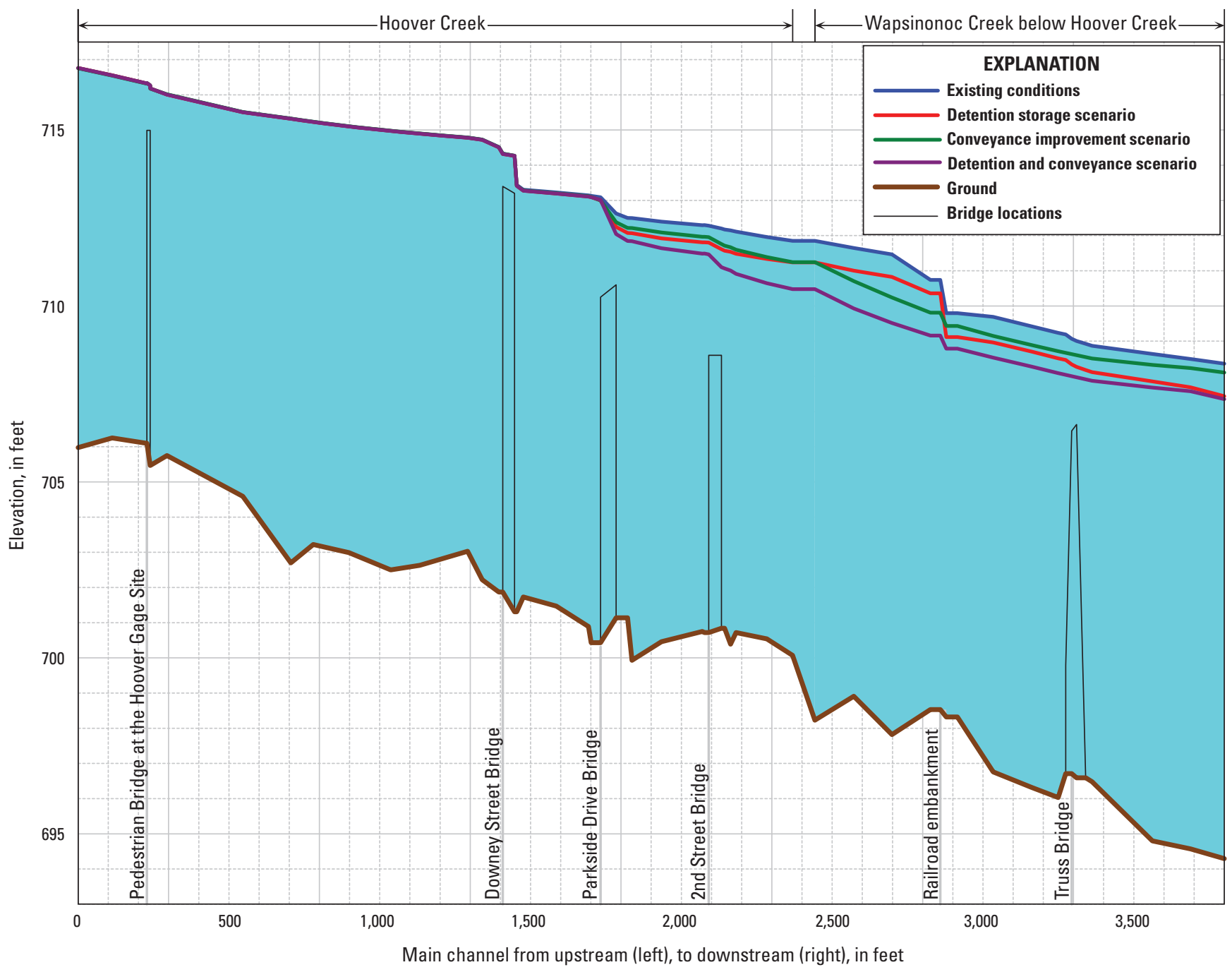

Figure 19. Results from simulation of a design rainfall event with 2-percent annual exceedance probability with water-surface profiles of Hoover Creek and Wapsinonoc Creek downstream from Hoover Creek. 


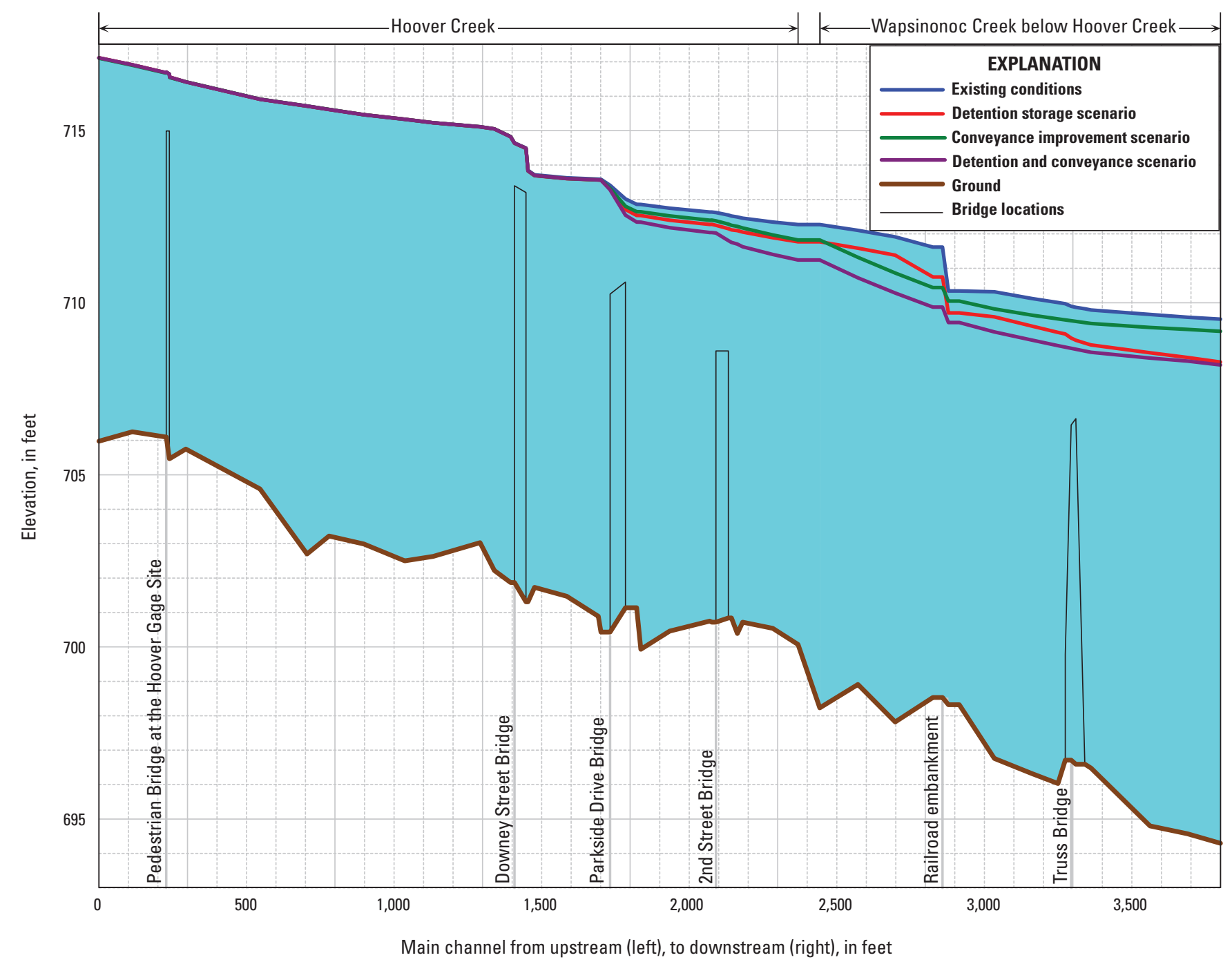

Figure 20. Results from simulation of a design rainfall event with 1-percent annual exceedance probability with water-surface profiles of Hoover Creek and Wapsinonoc Creek downstream from Hoover Creek. 
Table 10. Water-surface elevations from design rainfall events for the different flood mitigation scenarios compared to the existing conditions within the Wapsinonoc Creek watershed.

[WSE, water surface elevation; ft, feet; diff, difference equals scenario water-surface elevation minus existing conditions water-surface elevation; \%, percent; AEP, annual exceedence probability]

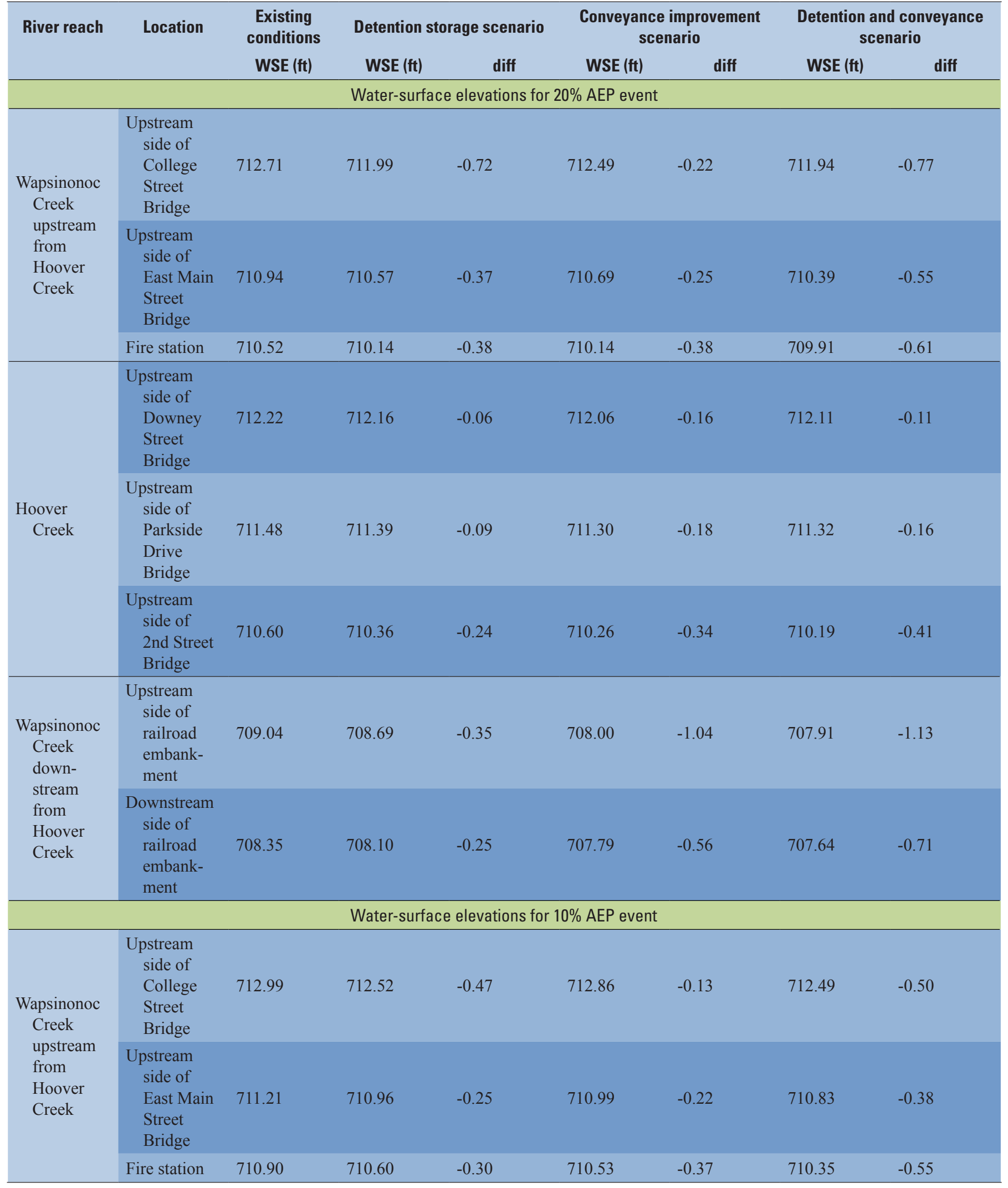


Table 10. Water-surface elevations from design rainfall events for the different flood mitigation scenarios compared to the existing conditions within the Wapsinonoc Creek watershed.-Continued

[WSE, water surface elevation; ft, feet; diff, difference equals scenario water-surface elevation minus existing conditions water-surface elevation; \%, percent; AEP, annual exceedence probability]

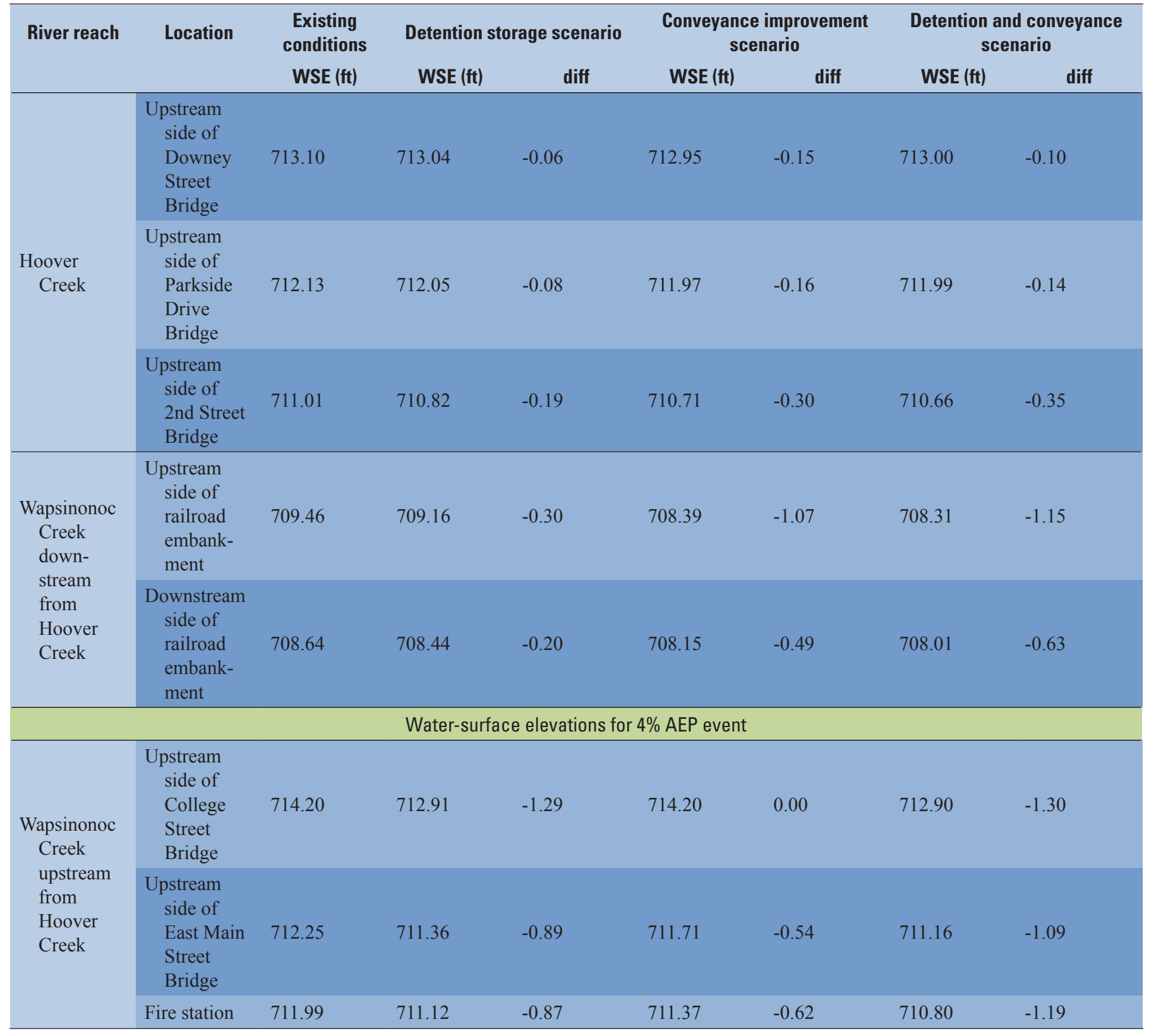


Table 10. Water-surface elevations from design rainfall events for the different flood mitigation scenarios compared to the existing conditions within the Wapsinonoc Creek watershed.-Continued

[WSE, water surface elevation; ft, feet; diff, difference equals scenario water-surface elevation minus existing conditions water-surface elevation; \%, percent; AEP, annual exceedence probability]

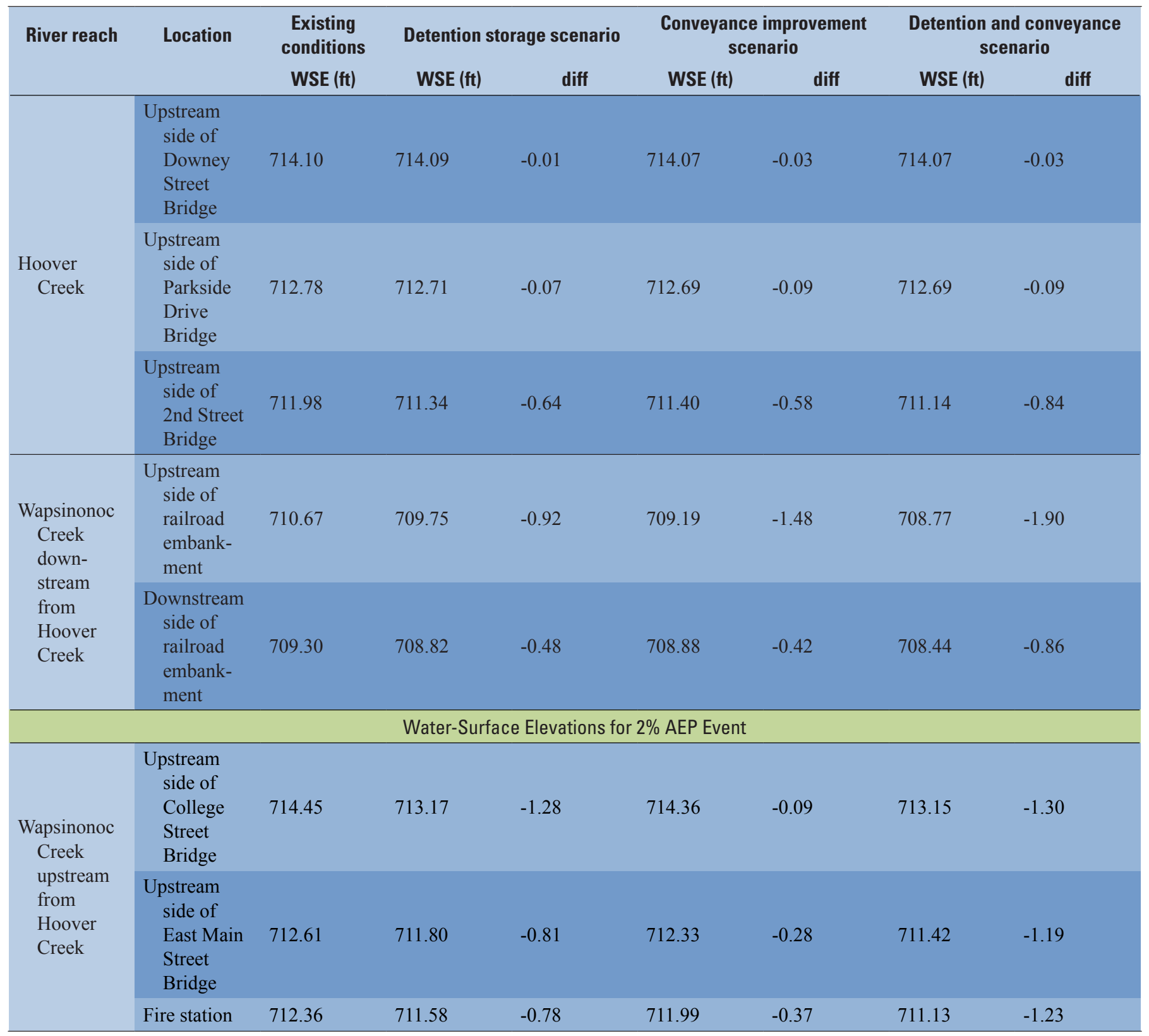


Table 10. Water-surface elevations from design rainfall events for the different flood mitigation scenarios compared to the existing conditions within the Wapsinonoc Creek watershed.-Continued

[WSE, water surface elevation; ft, feet; diff, difference equals scenario water-surface elevation minus existing conditions water-surface elevation; \%, percent; AEP, annual exceedence probability]

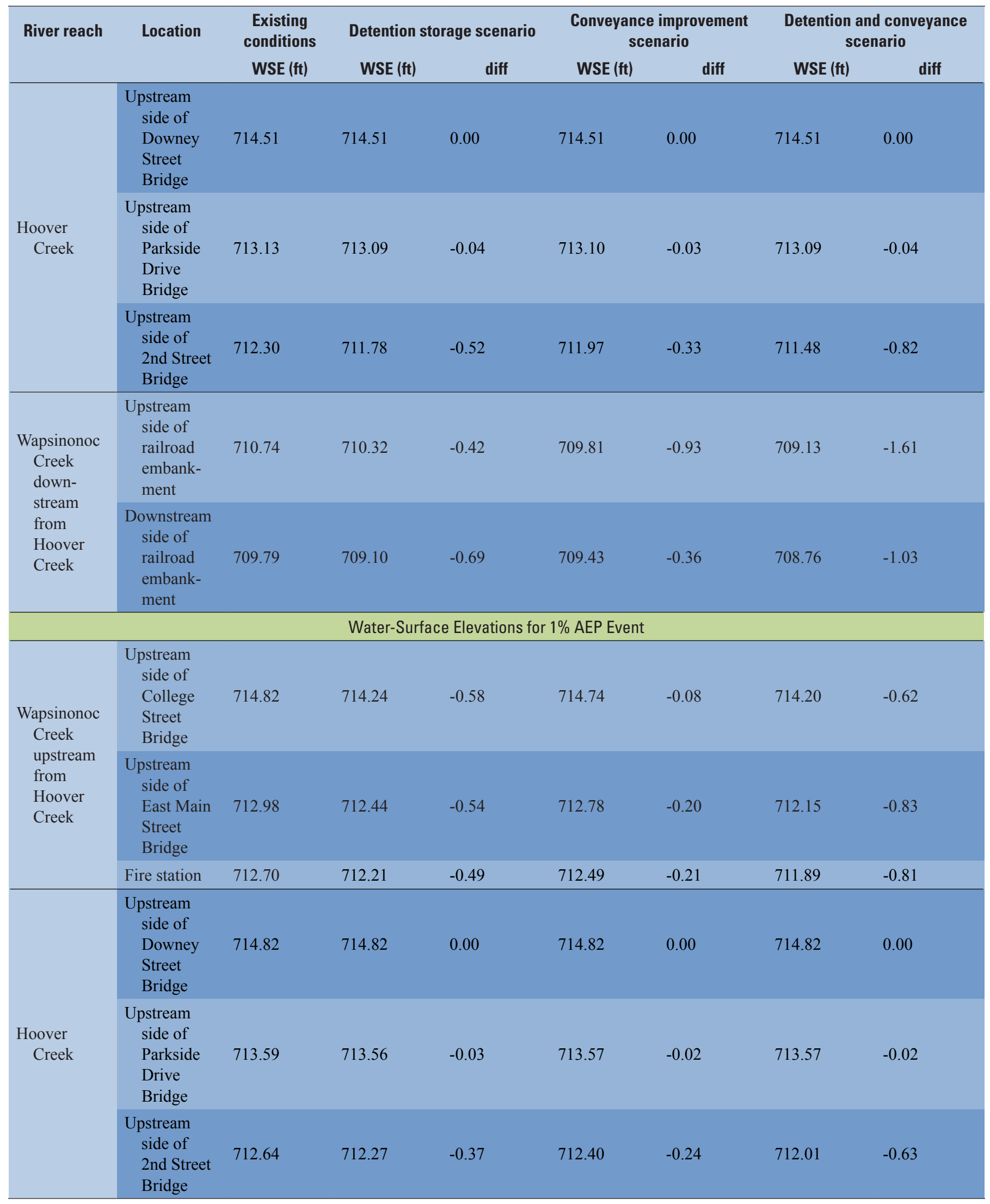


Table 10. Water-surface elevations from design rainfall events for the different flood mitigation scenarios compared to the existing conditions within the Wapsinonoc Creek watershed.-Continued

[WSE, water surface elevation; ft, feet; diff, difference equals scenario water-surface elevation minus existing conditions water-surface elevation; \%, percent; AEP, annual exceedence probability]

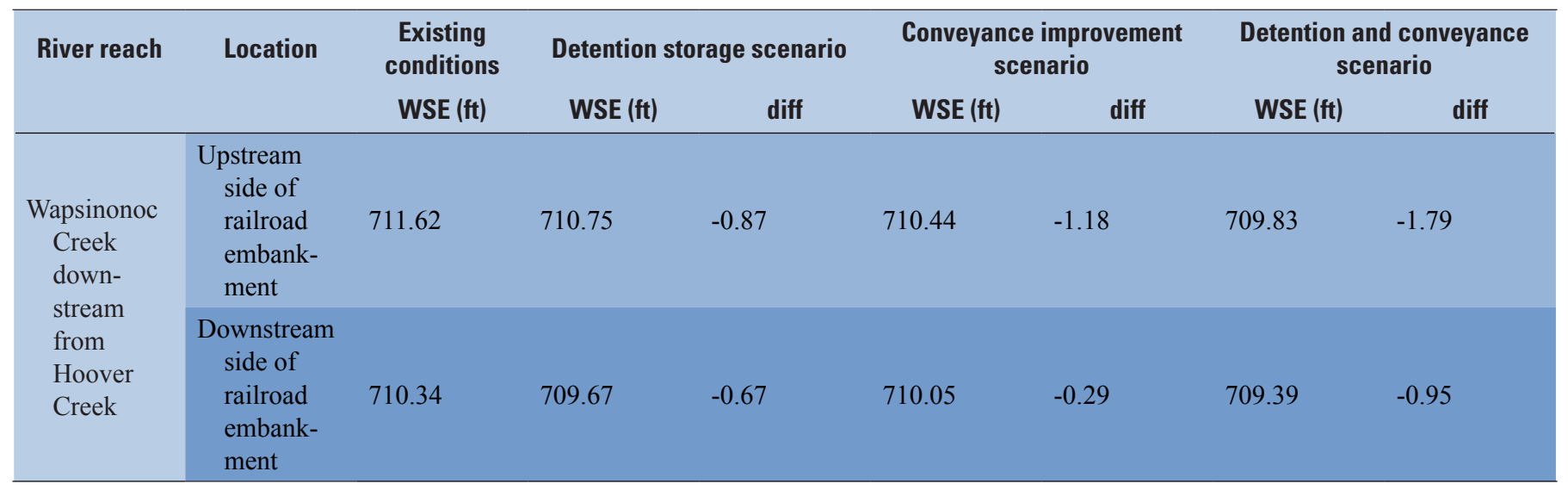

on the upstream sides of the East Main Street Bridge, College Street Bridge, and adjacent to the fire station had lower WSEs ranging from 0.38 to $1.30 \mathrm{ft}$. The values of WSEs on the upstream side of the 2nd Street Bridge had 0.35 to $0.84 \mathrm{ft}$ in lower WSEs. The values of WSEs on the upstream sides of the Downey Street and Parkside Drive bridges had the least improvement; decreases in WSEs ranged from 0.00 to $0.16 \mathrm{ft}$.

\section{Summary}

Hydrologic and hydraulic models were constructed for the Wapsinonoc Creek watershed in order to assess the effects of three flood-mitigation scenarios: detention storage, conveyance improvement, and combining the detention storage with the conveyance improvement. A model of existing conditions was also constructed to provide a baseline for the floodmitigation improvements. The existing-conditions model was calibrated to three historic storm events: June 30, 2014, July 12, 2014, and June 15, 2015. The existing-conditions model was calibrated using U.S. Geological Survey streamgages (05464942, 0546494170, 0546494140, 0546494150), U.S. Geological Survey precipitation gages (414345091253801, 414209091215801, 414208091204701), and surveyed highwater marks. The flood-mitigation scenarios and existingconditions models were simulated with 20-, 10-, 4-, 2-, and 1-percent annual exceedance probability design rainfall events in order to provide a large range of flows for evaluation.

The detention-storage scenario had the greatest effect upstream from the East Main Street Bridge, but moderate effects were seen throughout the Wapsinonoc stream reaches and in the Hoover reach to just upstream from the 2nd Street Bridge because this area receives overbank flow from the Wapsinonoc Creek. The conveyance-improvement scenario had the best improvement near the railroad embankment and upstream to the 2nd Street Bridge on Hoover Creek and the East Main Street Bridge on the Wapsinonoc Creek. The detention storage with conveyance-improvement scenario provided the most improvement for the Wapsinonoc stream reaches and the Hoover stream reach from its confluence with the Wapsinonoc Creek to just above the 2nd Street Bridge. Areas upstream the Parkside Drive Bridge on the Hoover Creek had little to no improvement with the flood-mitigation scenarios on the Wapsinonoc Creek.

\section{References Cited}

Barnes, H.H., Jr., 1967, Roughness characteristics of natural channels: U.S. Geological Survey Water-Supply Paper $1849,219 \mathrm{p}$.

Chow, V.T., 1959, Open-channel hydraulics: McGraw-Hill, $680 \mathrm{p}$.

Chow, V.T., Maidment, D.R., and Mays, L.W., Jr., 1988, Applied hydrology: New York, McGraw-Hill Book Company, $572 \mathrm{p}$.

Clark, C.O., 1945, Storage and the unit hydrograph: Transactions of the American Society of Civil Engineers, v. 110, p. 1419-1488.

Eash, D.A., 2015, Comparisons of estimates of annual exceedance-probability discharges for small drainage basins in Iowa, based on data through water year 2013: U.S. Geological Survey Scientific Investigations Report 2015-5055, 37 p., https://dx.doi.org/10.3133/sir20155055.

Federal Emergency Management Agency, 2013, Flood insurance study, Cedar County and incorporated areas: Washington D.C., 25 p. 
Gupta, H.V., Sorooshian, S., and Yapo, P.O., 1999, Status of automatic calibration for hydrologic models - Comparison with multilevel expert calibration: Journal of Hydrologic Engineering, v. 4, no. 2, p. 135-143.

Homer, C.G., Dewitz, J.A., Yang, L., Jin, S., Danielson, P., Xian, G., Coulston, J., Herold, N.D., Wickham, J.D., and Megown, K., 2015, Completion of the 2011 National Land Cover Database for the conterminous United StatesRepresenting a decade of land cover change information: Photogrammetric Engineering and Remote Sensing, v. 81, no. 5 , p. 345-354.

Iowa Highway Research Board, 1957, Drainage areas of Iowa streams: Bulletin 7, $440 \mathrm{p}$.

Iowa Institute of Hydraulic Research, 2010, Hoover Creek Watershed National Park Service and flood reduction project: Iowa City, Iowa, 45 p.

Moriasi, D.N., Arnold, J.G., Van Liew, M.W., Binger, R.L., Harmel, R.D., and Veith, T.L, 2007, Model evaluation guidelines for systematic quantification of accuracy in watershed simulations: Transactions of the American Society of Agricultural and Biological Engineers, v. 50, no. 3, p. 885-900.

Nash, J.E., and Sutcliffe, J.V., 1970, River flow forecasting through conceptual models part 1-A discussion of principles: Journal of Hydrology, v. 10, p. 282-290.

National Oceanic and Atmospheric Administration, 2016, National Centers for Environmental Information: NEXRAD Data Archive, Inventory and Access, accessed March 11, 2016, at https://www.ncdc.noaa.gov/nexradinv/.

National Park Service (NPS), 2006, Final Hoover Creek stream management plan and environmental impact statement: Washington D.C., 267 p.

Nation Park Service (NPS), 2017, NPS Herbert Hoover National Historic Site, accessed January 10, 2018, at http://www.nps.gov/heho/index.htm.

Natural Resources Conservation Service, 2004, Chapter 10Estimation of direct runoff from storm rainfall-Part 630 hydrology —National engineering handbook: Washington, D.C., U.S. Department of Agriculture, 22 p.

Norfleet, G.R., 2013, Dam stopped repeat of 1993: West Branch Times, accessed January 10, 2018, at http://www.westbranchtimes.com/article.php?id=9295.

Parsons Engineering Corporation, 2006, Engineering reportStream management plan for the Herbert Hoover national historic site, West Branch, Iowa: Chicago, 43 p.
Perica, Sanja, Martin, Deborah, Pavlovic, Sandra, Roy, Ishani, St. Laurent, Michael, Trypaluk, Carl, Unruh, Dale, Yekta, Michael, Bonnin, Geoffrey, 2013, Precipitation-frequency atlas of the United States-NOAA atlas 14: Silver Spring, Md., U.S. Department of Commerce, v. 8, ver. 2.0, 289 p.

Prior, J.C., 1991, Landforms of Iowa: Iowa City, University of Iowa Press, $154 \mathrm{p}$.

Soil Conservation Service (SCS), 1986, Urban hydrology for small watersheds-TR 55: Washington, D.C., U.S. Department of Agriculture, $98 \mathrm{p}$.

State of Iowa, 2017, Office of the Chief Information Officer, Iowa Geodata, accessed July 2017, at https://geodata.iowa.gov.

U.S. Army Corps of Engineers (USACE), 1994, Flood-runoff analysis-Engineer manual: Washington D.C., Department of the Army, no. 1110-2-1417, $196 \mathrm{p}$.

U.S. Army Corps of Engineers (USACE), 2012, Hydrologic engineering center geospatial river analysis extension 10 user's manual: Davis, Calif., Hydrologic Engineering Center, $242 \mathrm{p}$.

U.S. Army Corps of Engineers (USACE), 2013, Hydrologic engineering center geospatial hydrologic modeling extension 10.1 user's manual: Davis, Calif., Hydrologic Engineering Center, $193 \mathrm{p}$.

U.S. Army Corps of Engineers (USACE), 2016a, Hydrologic engineering center hydrologic modeling system HEC-HMS 4.2 user's manual: Davis, Calif., Hydrologic Engineering Center, $598 \mathrm{p}$.

U.S. Army Corps of Engineers (USACE), 2016b, Hydrologic engineering center river analysis system HEC-RAS 5.0 user's manual: Davis, Calif., Hydrologic Engineering Center, $960 \mathrm{p}$.

U.S. Census Bureau, 2010, Profile of general population and housing characteristics, 2010 demographic profile data for West Branch, Iowa: Washington, D.C., accessed July 2017, at https://factfinder.census.gov/faces/nav/jsf/pages/community_facts.xhtml.

U.S. Department of Agriculture, 2016, Geospatial Data Gateway, accessed April 8, 2016, at http://datagateway.nrcs.usda.gov/.

U.S. Geological Survey (USGS), 2016, USGS water data for Iowa: U.S. Geological Survey, National Water Information System-Web interface, accessed April 8, 2016, at https://waterdata.usgs.gov/nwis. 
For more information concerning this report, contact:

Director, Central Midwest Water Science Center U.S. Geological Survey

400 S. Clinton Street

lowa City, IA 52240

Publishing support by:

The USGS Science Publishing Network, Madison and Pembroke Publishing Service Centers 
